\title{
The Kurds and the phenomenon of migration In the Middle Ages (Analyzing study about the reasons and conclusions)
}

\author{
Mahdi Othman Haruti ${ }^{1}$
}

Received: June 07, 2016

Reviewed: June 14, 2016

Accepted: July 22, 2016

\begin{abstract}
Kurds have resorted to migration in different periods of the Islamic Middle Ages. This migration was happened by different reasons, and also resulted in multiple results. This research which is devoted to study this aspect, in the first attempts to write briefly about the beginning of Kurdish settling in their territories at the beginning of Islamic era. The research also talks about the different stages of Kurds emigration, and analyzes the motivations behind these migrations. Such as economic motives like famine (such as the migration of large groups of Erbil residents because of the drought that occurred in the year $1318 \mathrm{AD}$ ), or health and spread of diseases (such as this migration that happened in some of the Kurdish areas in the year 1348 AD). Or the political and military pressures (such as the attacks of Turk Ghazis and Saljuk and Mongol, which forced many Kurdish groups to migrate from the eastern Kurdish areas to the northern and western regions in different periods). Also the religious reasons had a role in this aspect. The Ayyubid and the Kurdish tribes that were with them had emigrated to Syria and Egypt in order to participate in the Crusades. In the end we mention the most important conclusions that resulted from those migrations. And analyze the social and economic consequences as well as the distribution of the population and the changes that have occurred within the border of the Kurdish provinces.
\end{abstract}

\section{Recommended citation:}

Haruti, M. O. (2016). The Kurds and the phenomenon of migration In the Middle Ages (Analyzing study about the reasons and conclusions). International Journal of Kurdish Studies 2 (3), 124 - 146.

\footnotetext{
${ }^{1}$ Lecturer, Department of history, Faculty of education, Koya University

Daniel Mitterrand Boulevard, Koya KOY45, Kurdistan Region - F.R. Iraq. E-mail; mahdiharuti@ gmail.com
} 


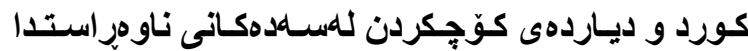

(تويَزينهو هيهكى شيكارييه للمبارهى هؤكارو دهرهنجامهكان)

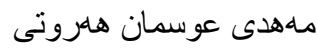

\section{يوخته:}

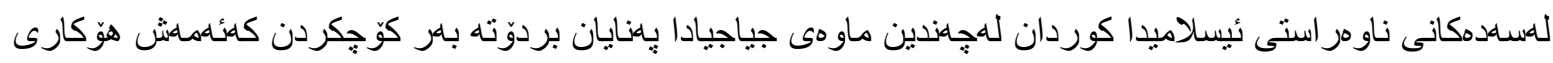

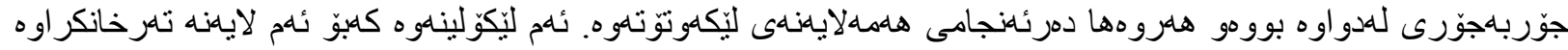

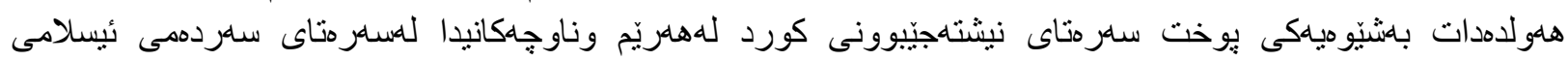

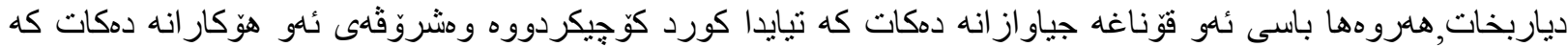

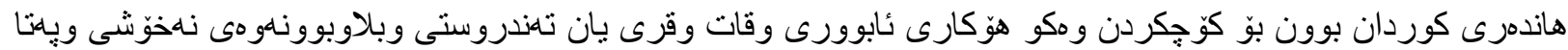

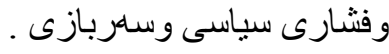

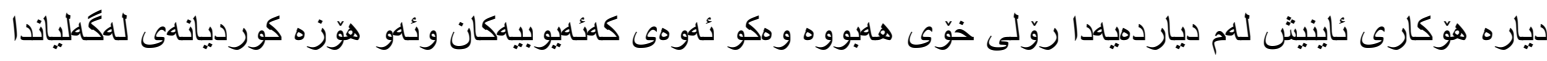

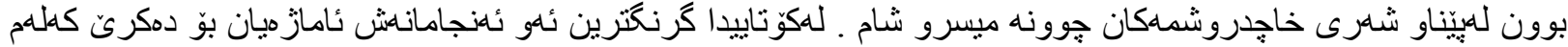

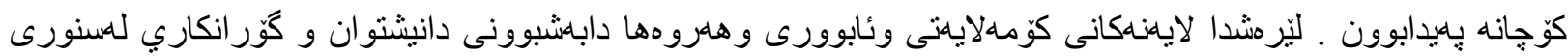
ناو جهكان شيكاريان بوّ دمكريّيت.

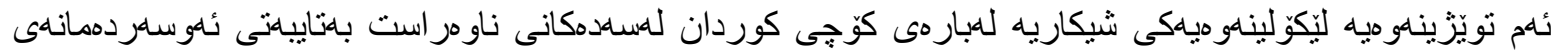

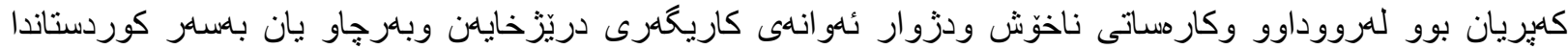

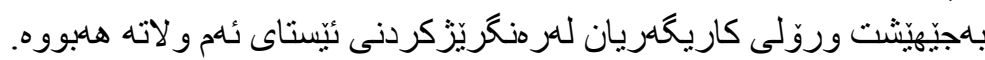

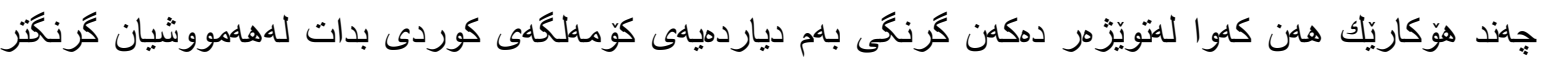

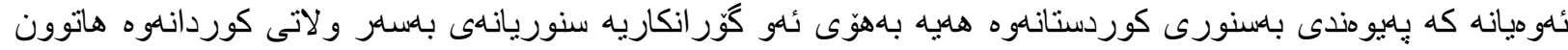

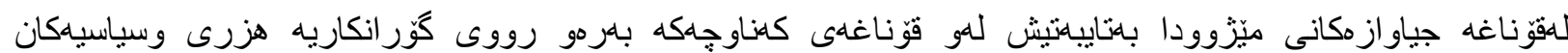

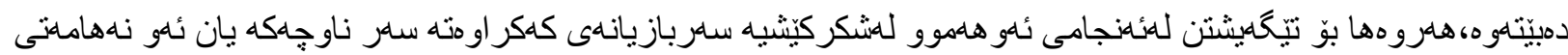

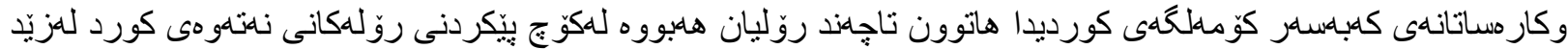

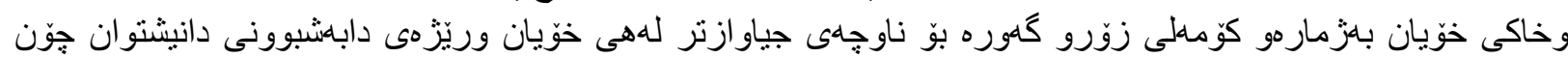

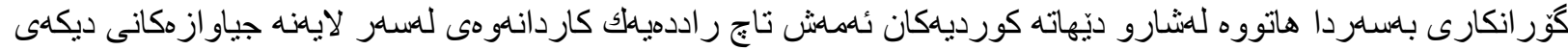

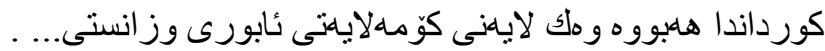

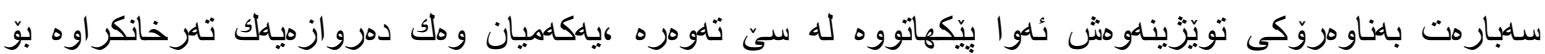

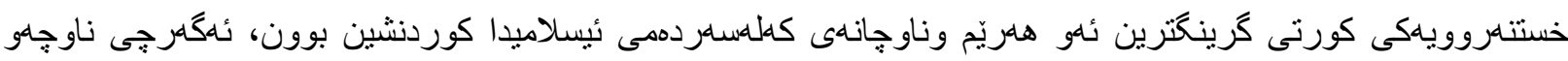

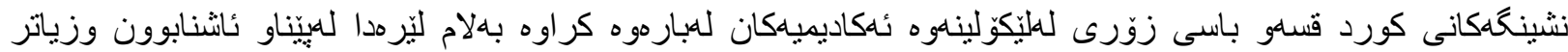

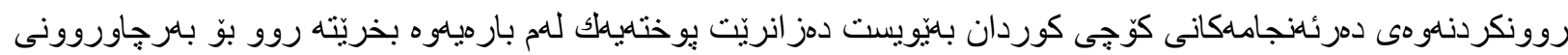

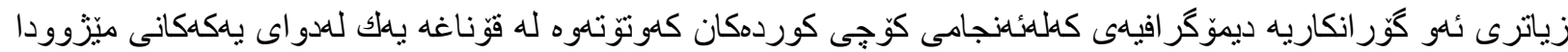

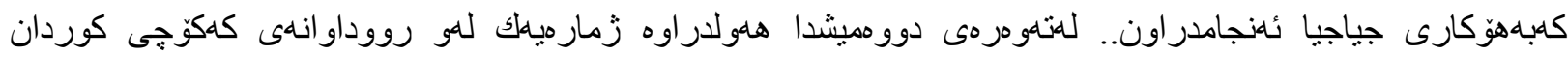

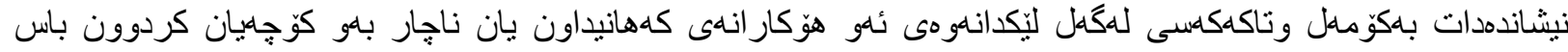

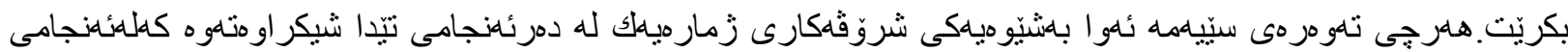

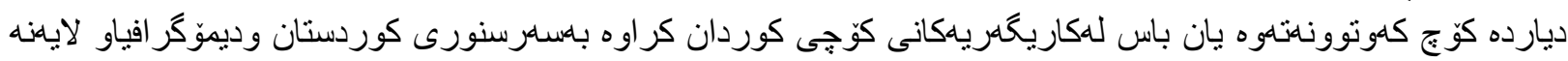

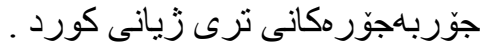




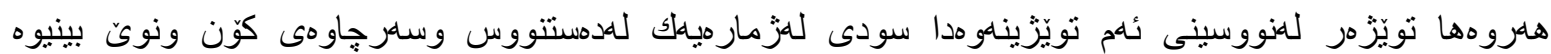

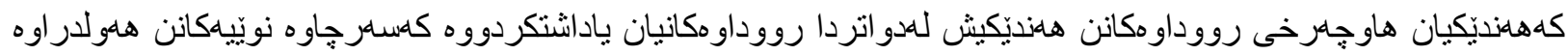

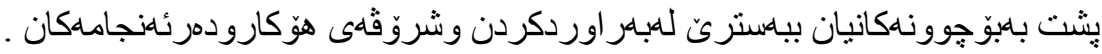

\section{تهوهرهى ياكهم:ناوجهكانى نيشتهجيّيوونى كوردان (وولاتى كوردان):}

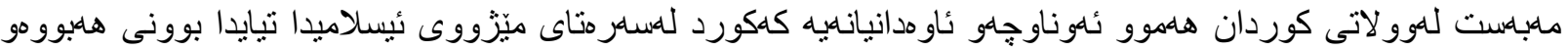

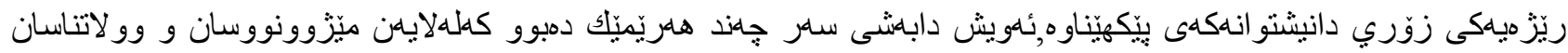

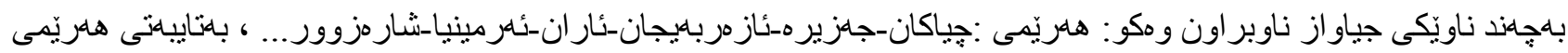

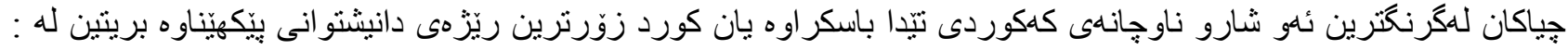

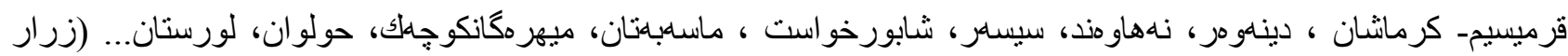

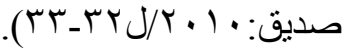

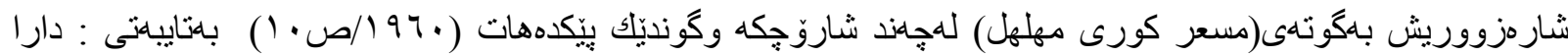

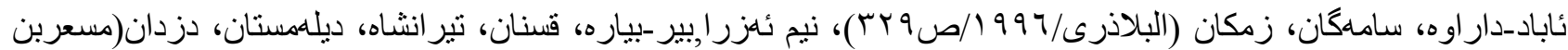

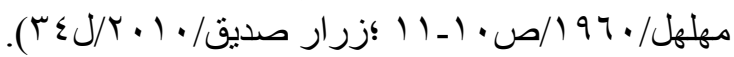

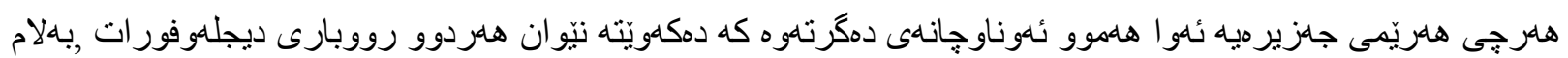

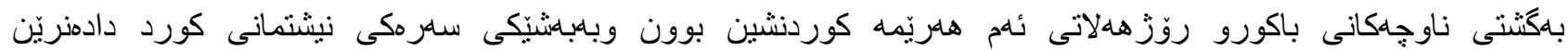

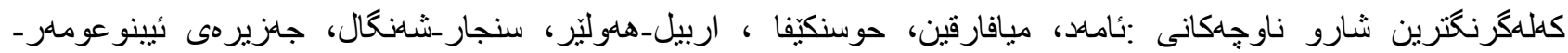

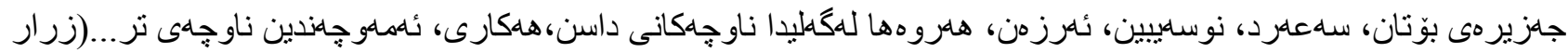

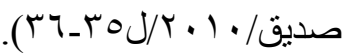

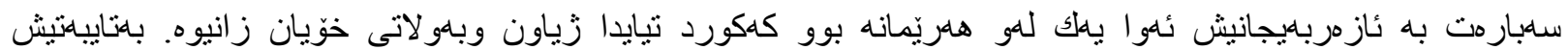

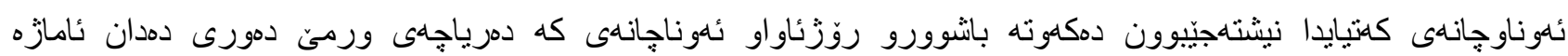

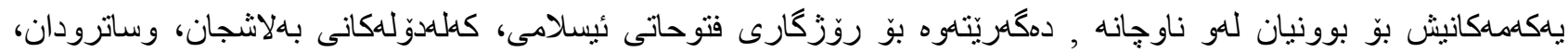

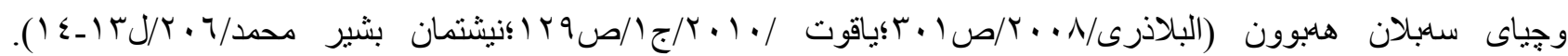

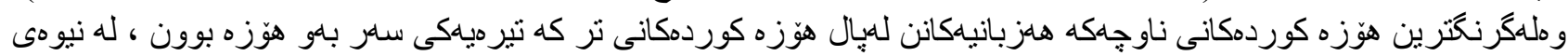

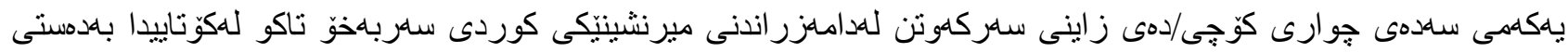

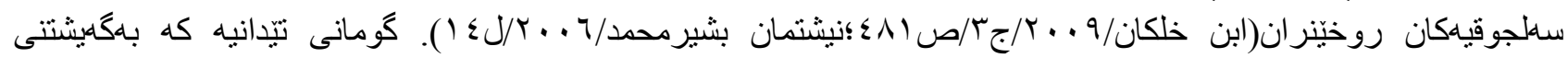

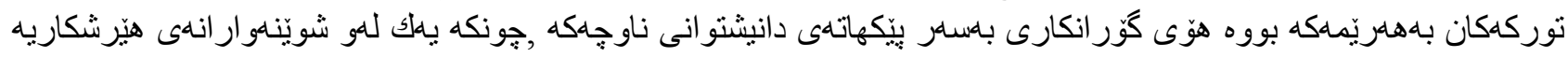

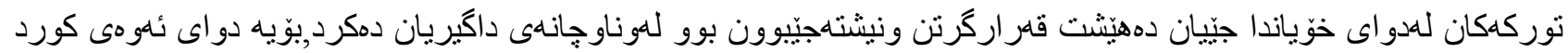

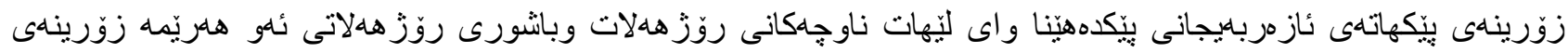

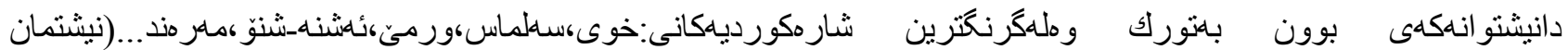

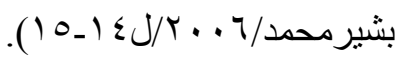

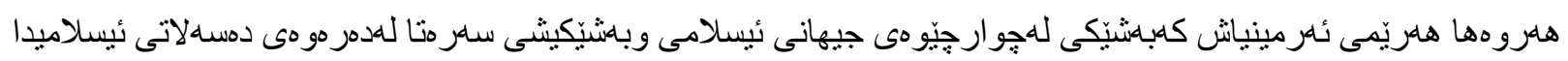

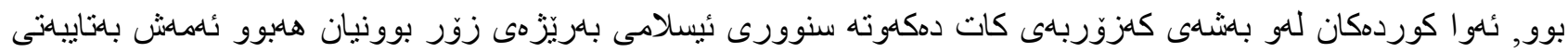

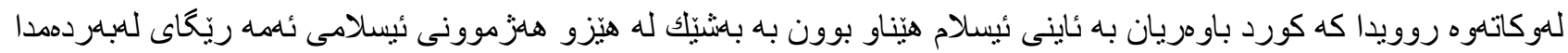

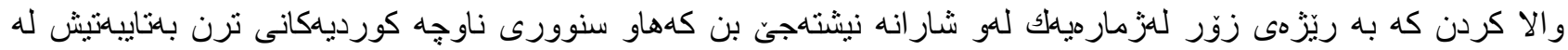

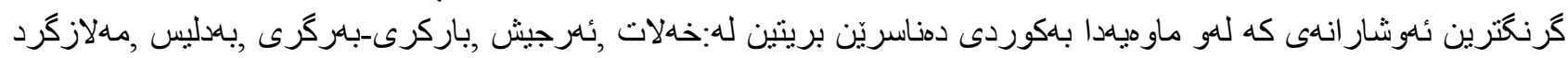
... (برو انه:ياشكوّى زماره (1) () ). 


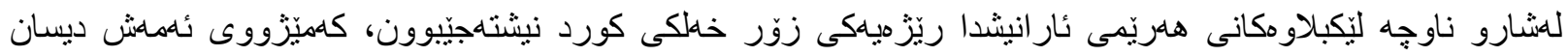

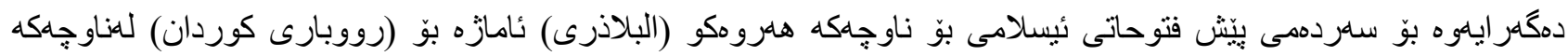

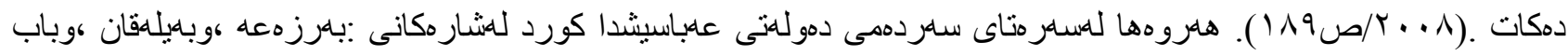

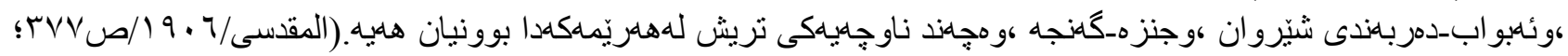

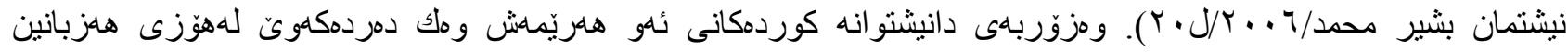

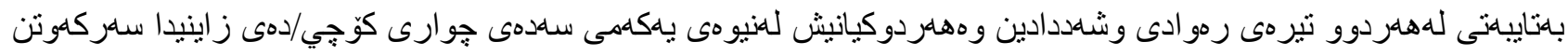

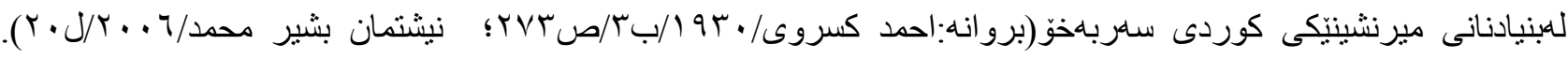

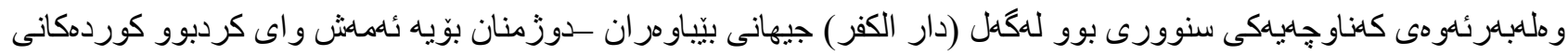

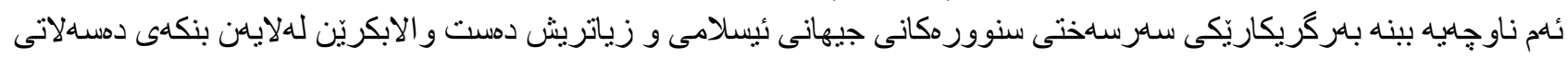

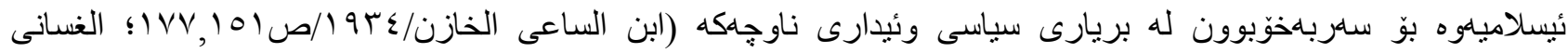

. (rYO, r.

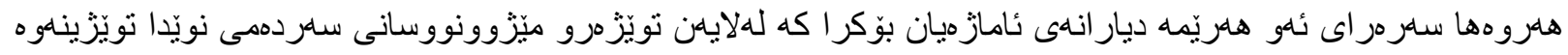

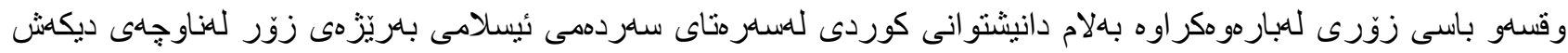

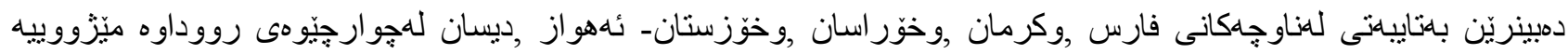

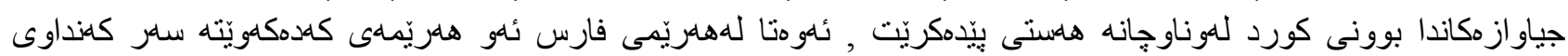

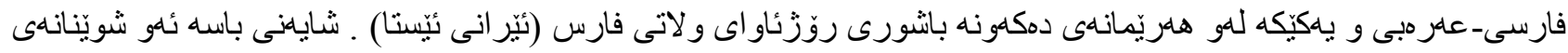

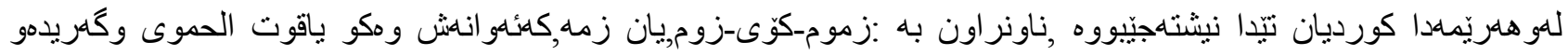

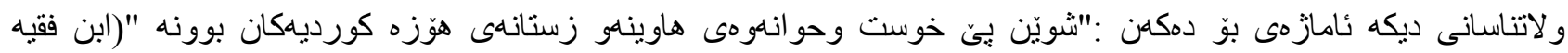

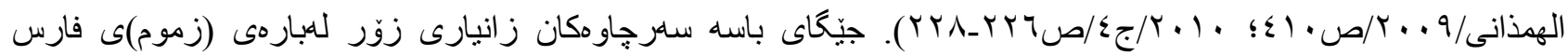

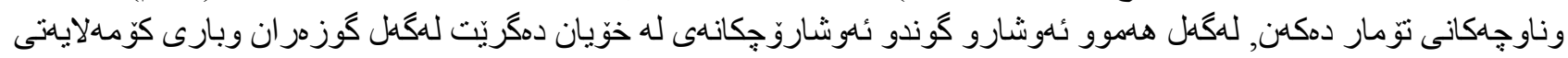

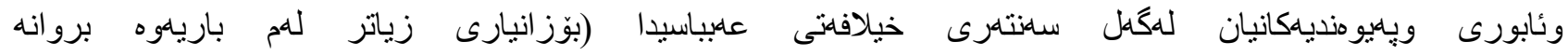

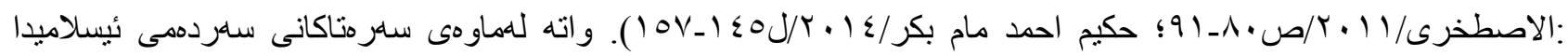

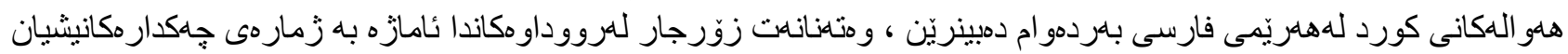

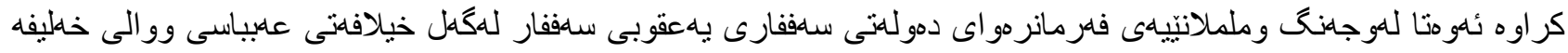

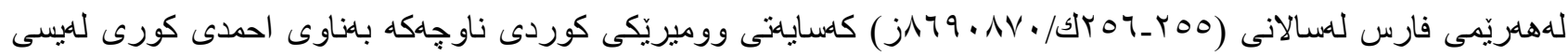

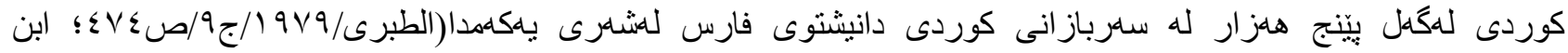

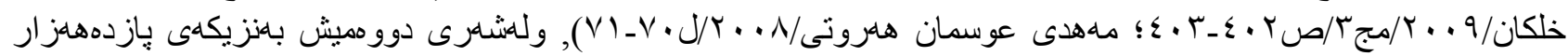

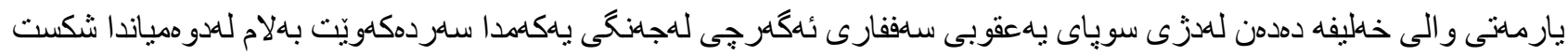

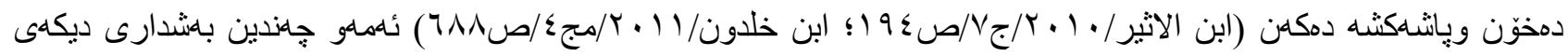

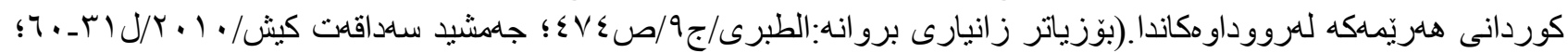

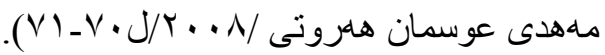

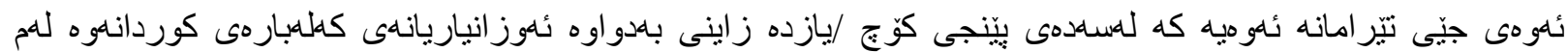

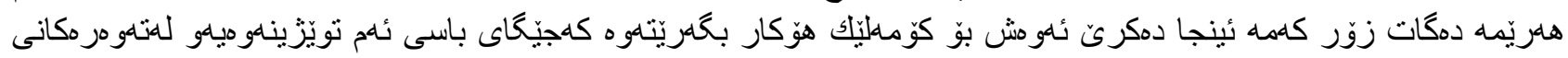

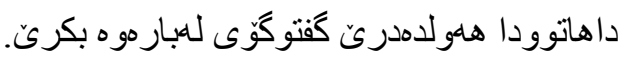

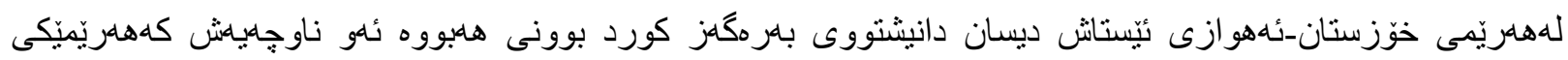

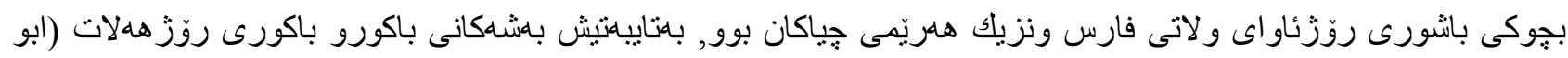

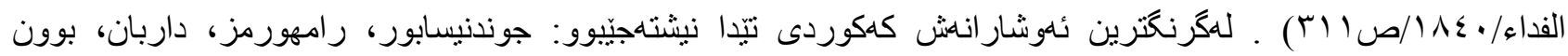

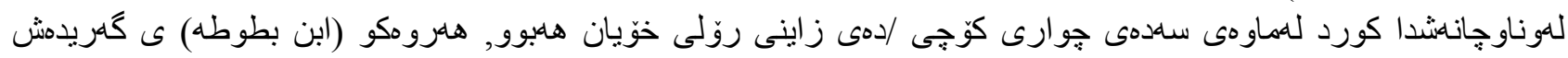

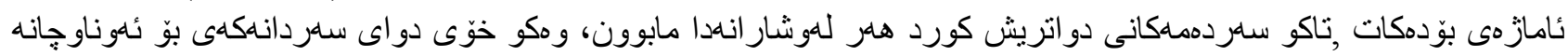

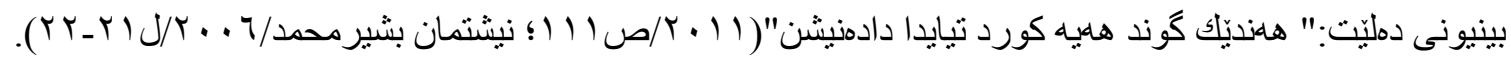

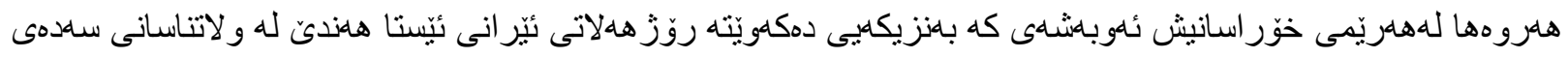

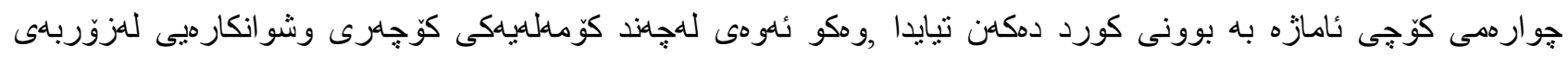




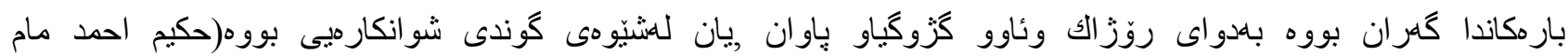

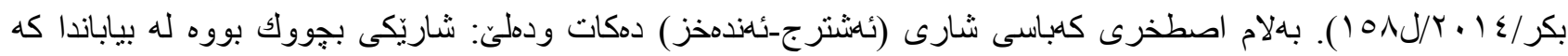

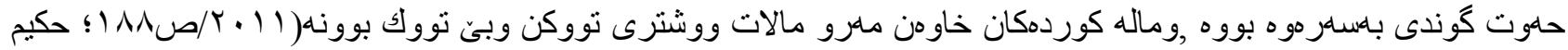

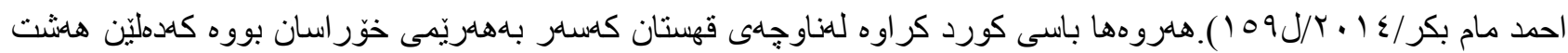

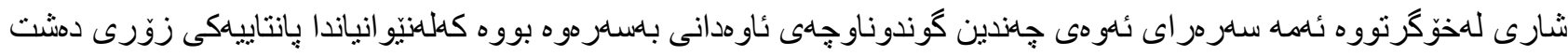

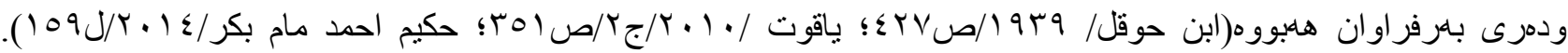

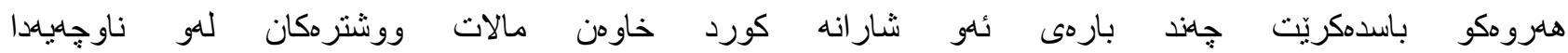

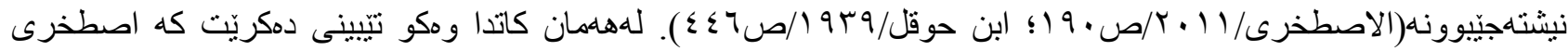

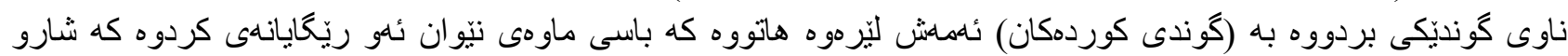

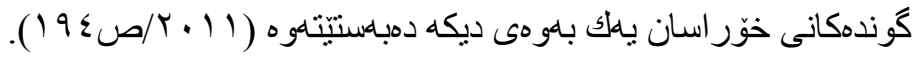

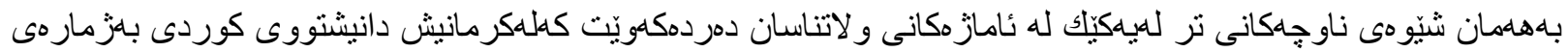

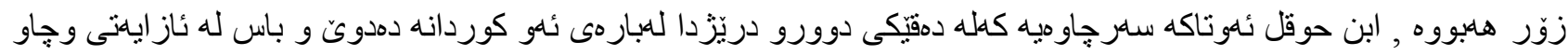

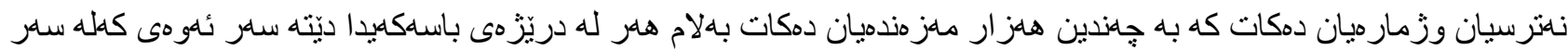

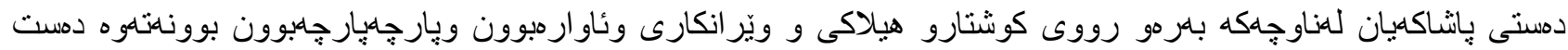

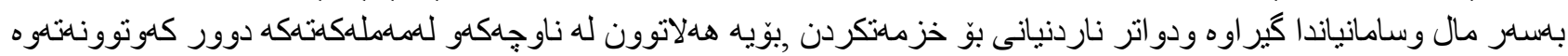

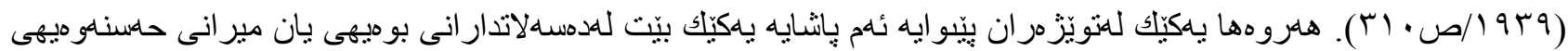

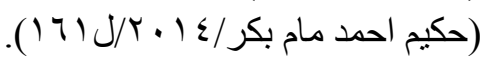

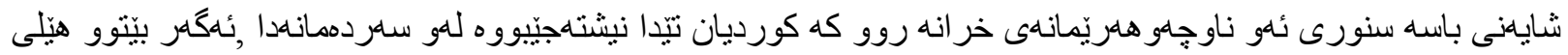

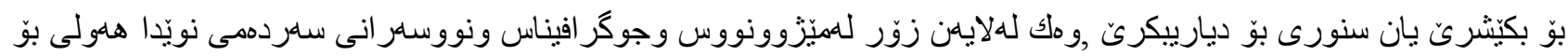

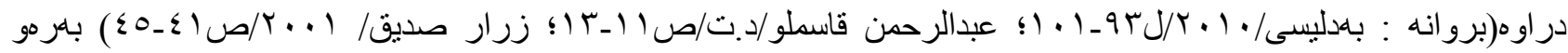

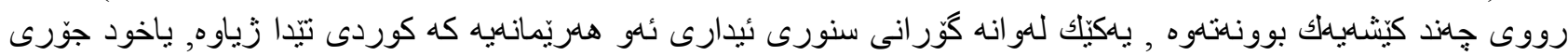

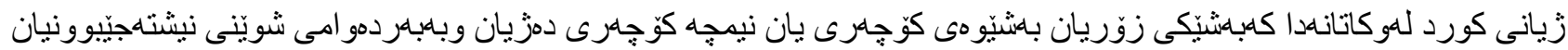

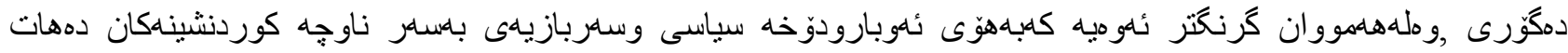

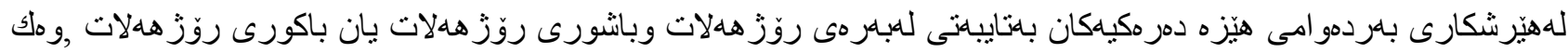

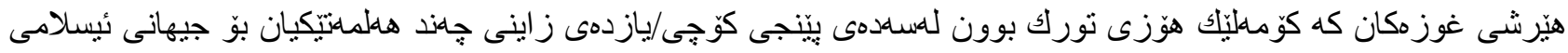

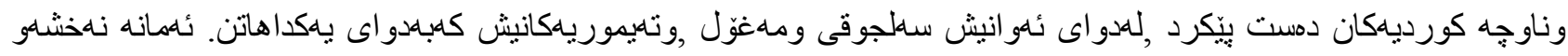

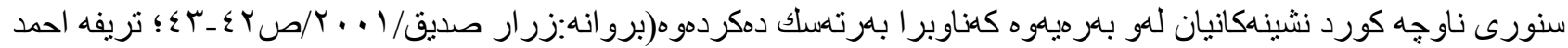

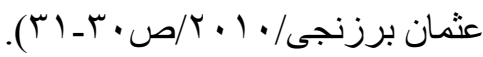

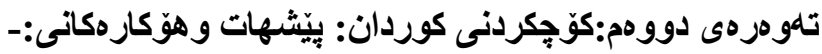

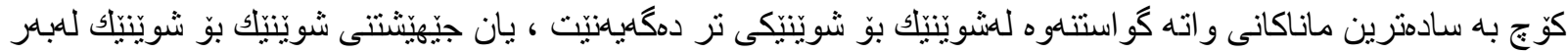

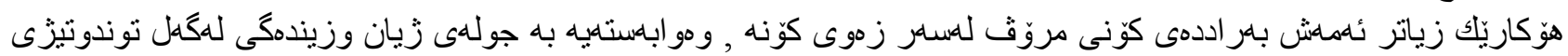

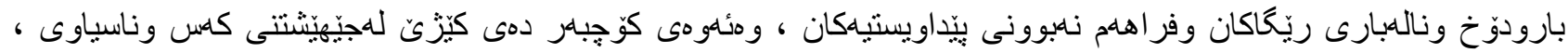

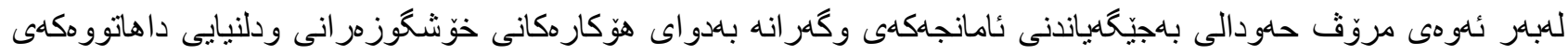

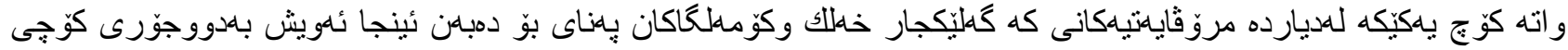

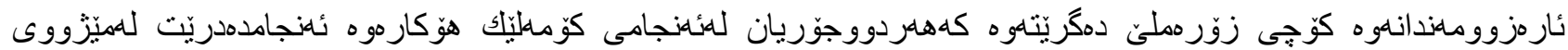

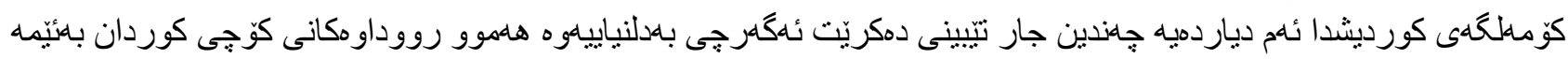

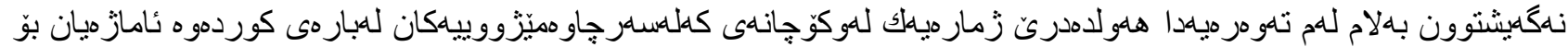

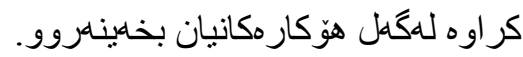




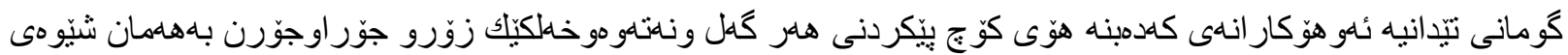

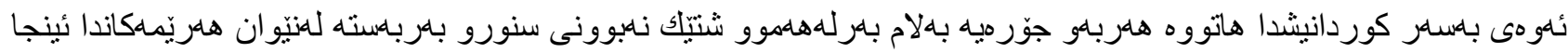

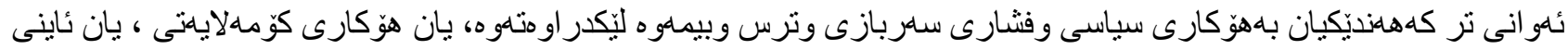

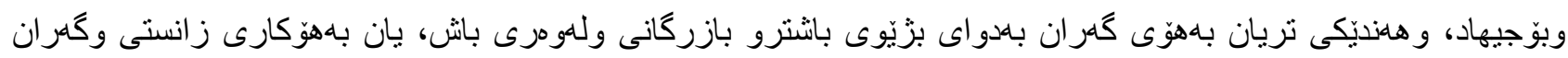

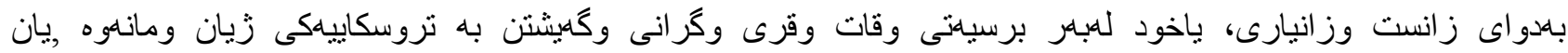

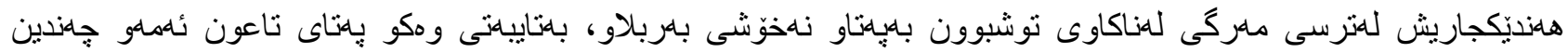

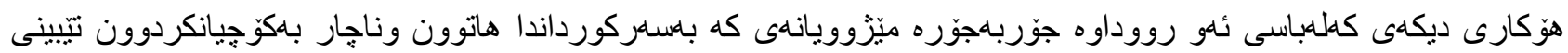
دمكريّت .

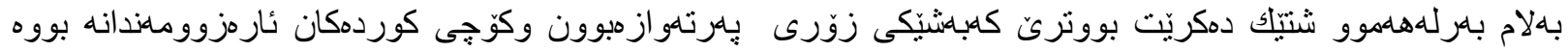

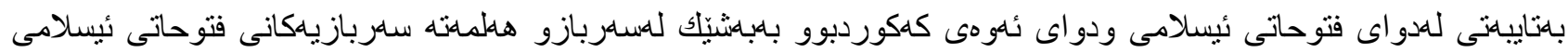

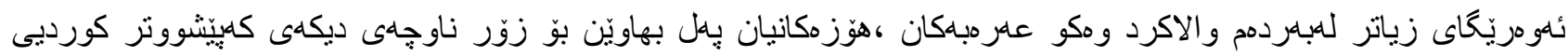

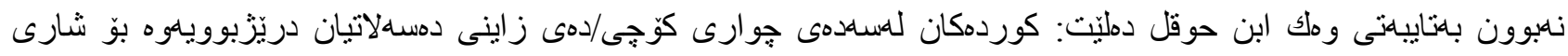

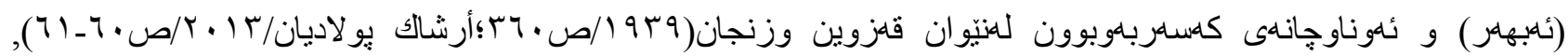

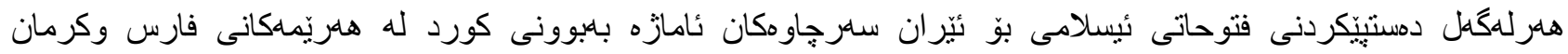

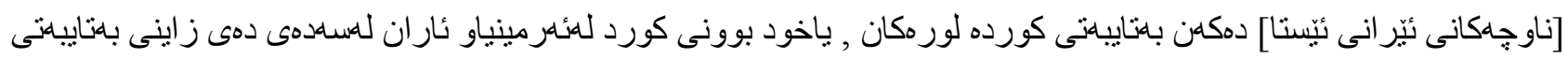

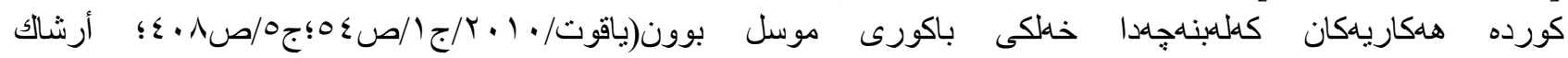

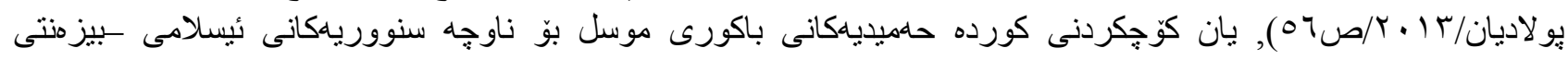

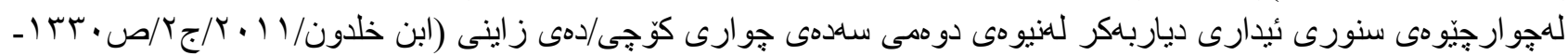

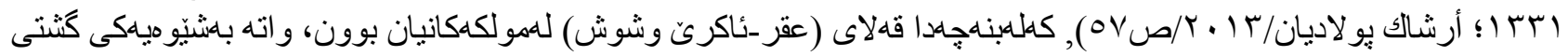

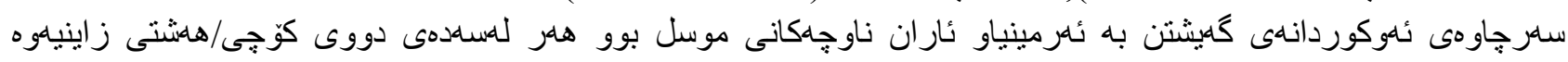

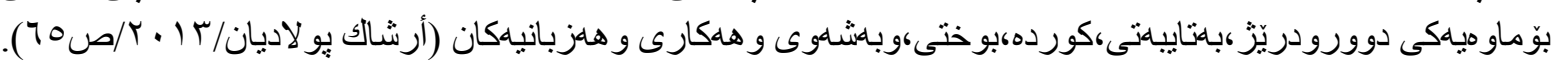

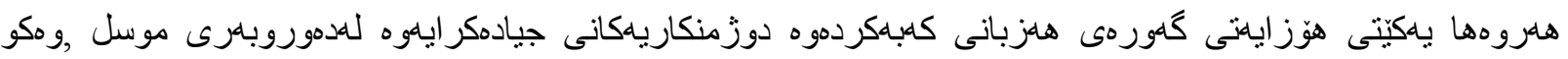

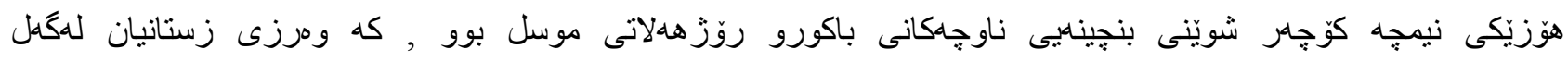

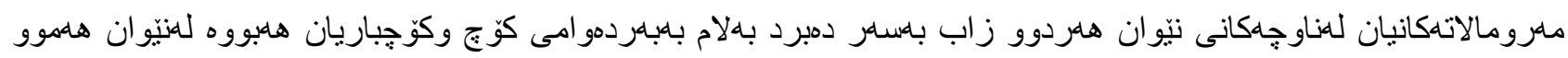

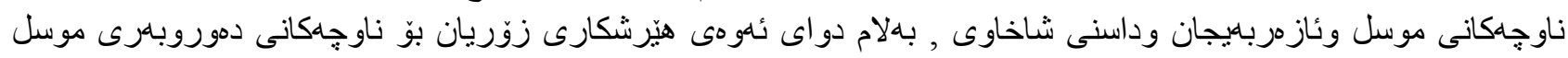

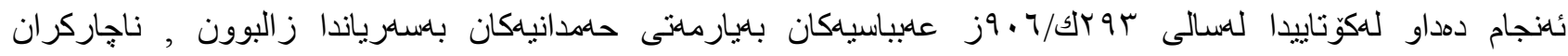

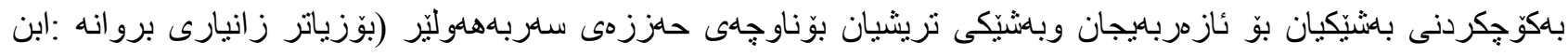

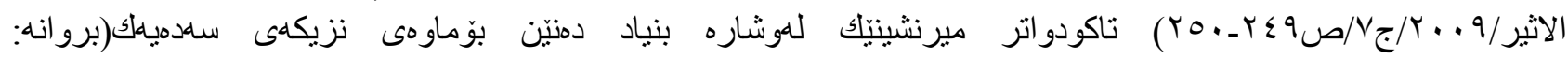

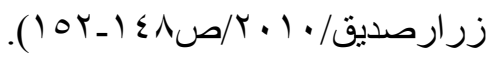

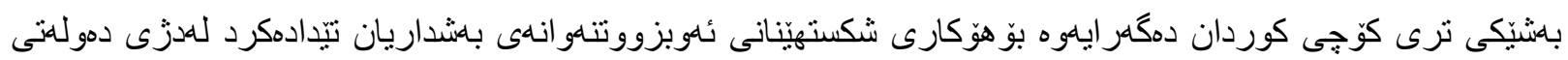

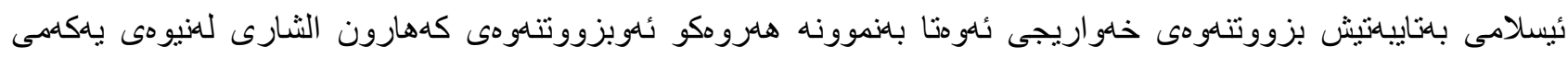

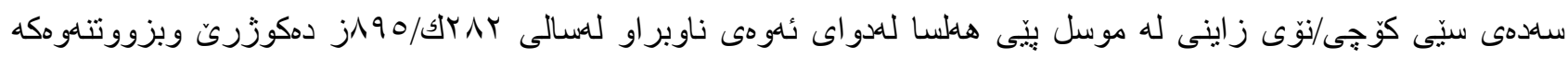

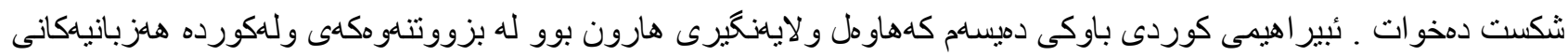

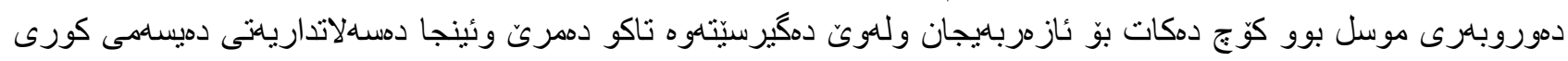

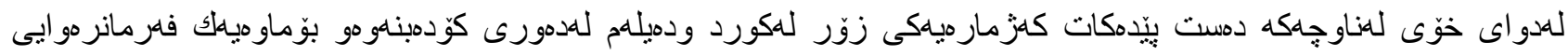

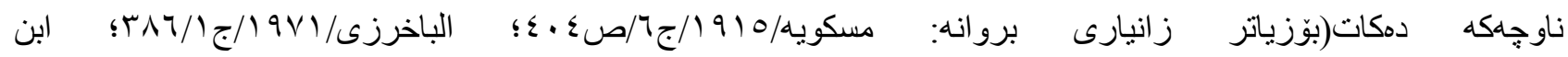

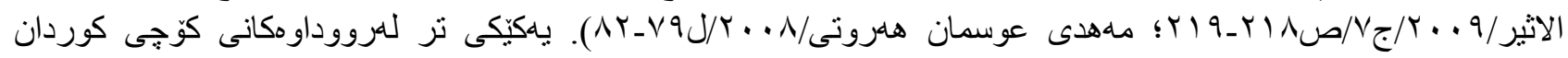

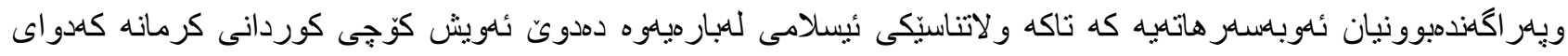

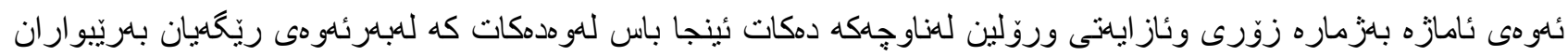

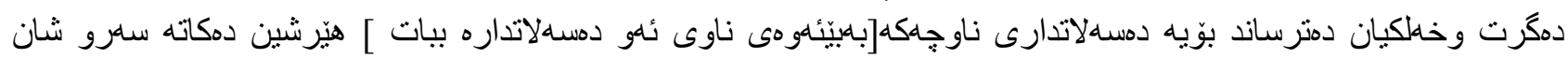

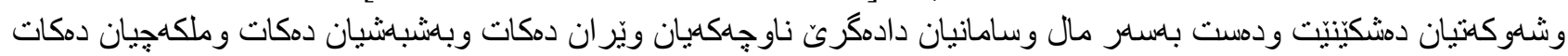

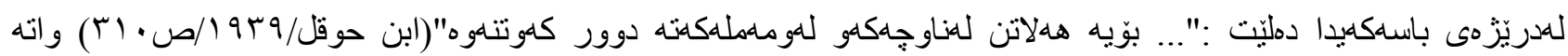

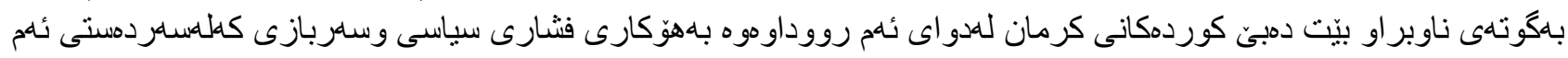




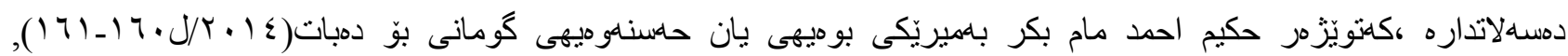

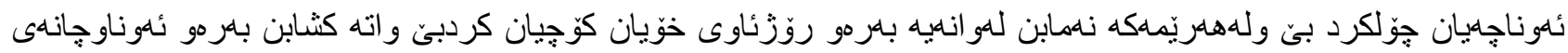

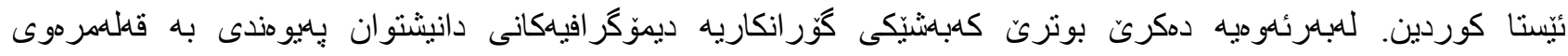

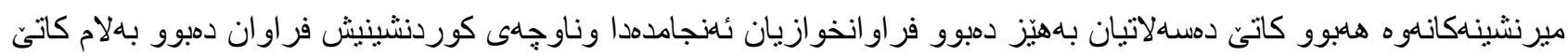

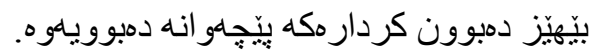

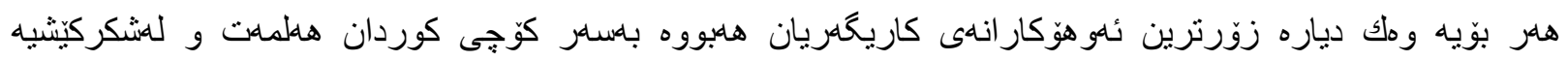

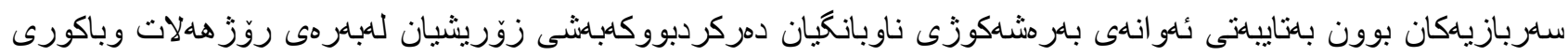

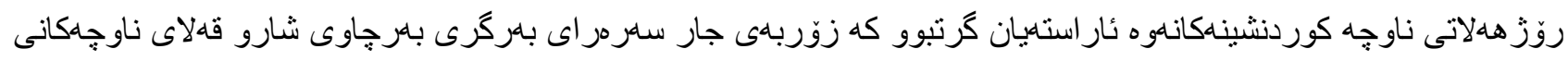

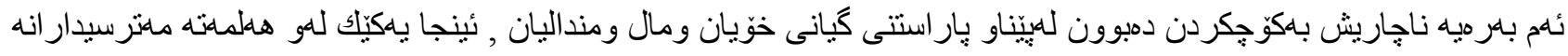

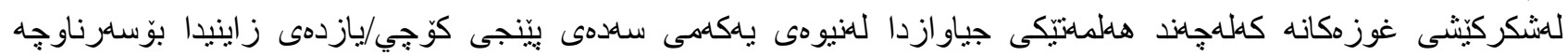

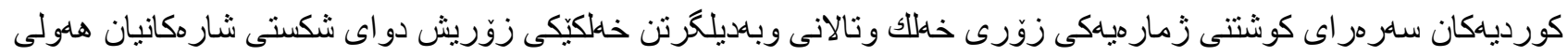

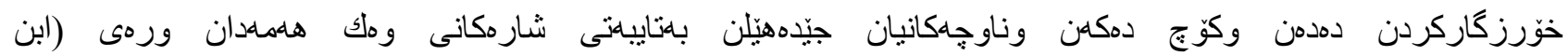

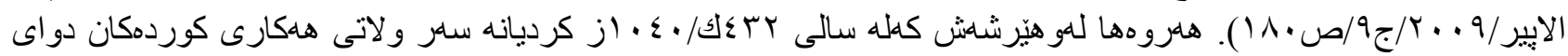

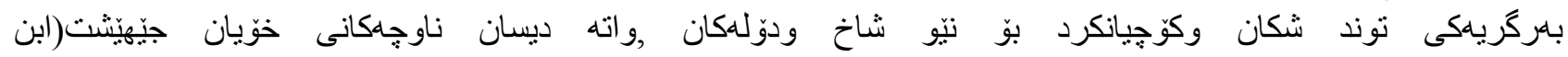

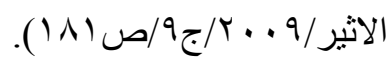

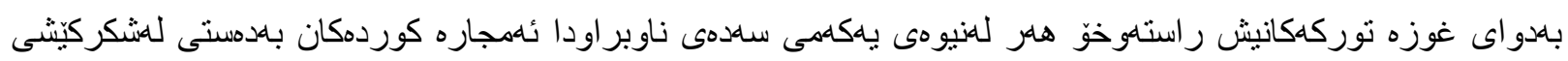

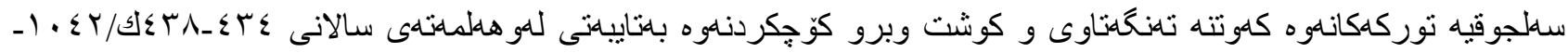

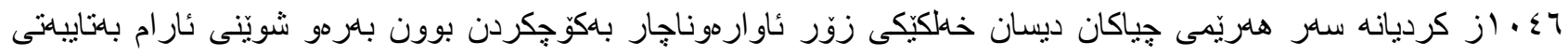

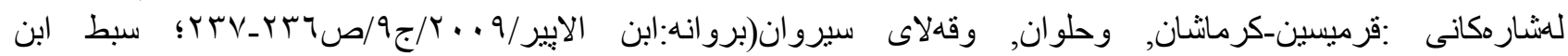

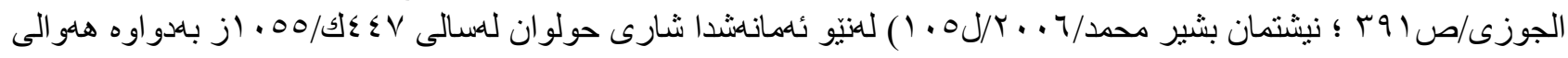

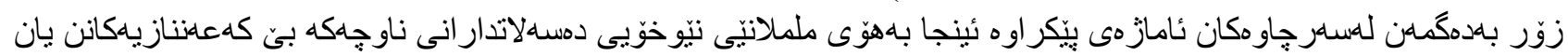

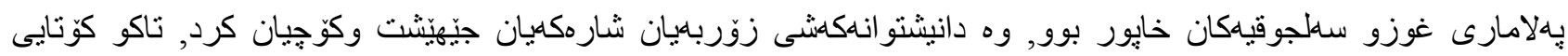

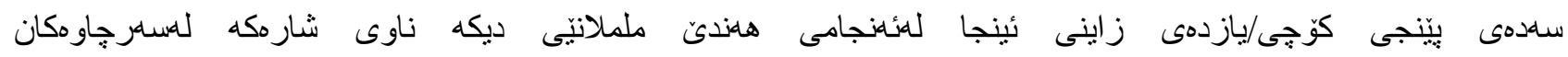

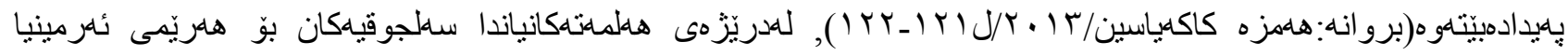

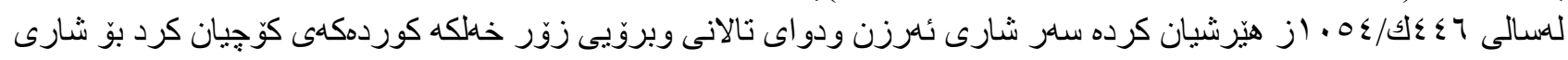

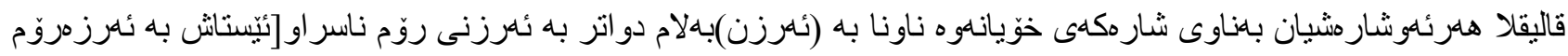

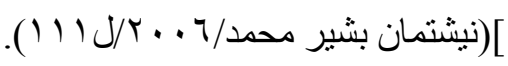

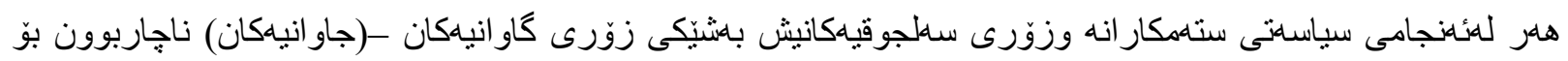

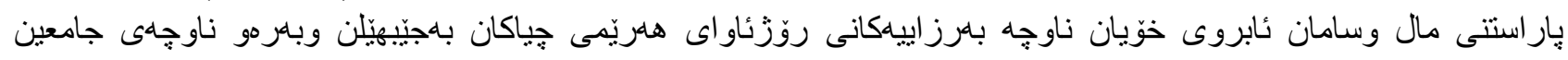

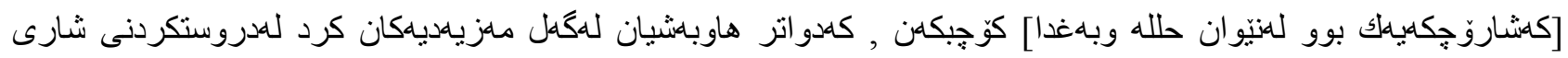

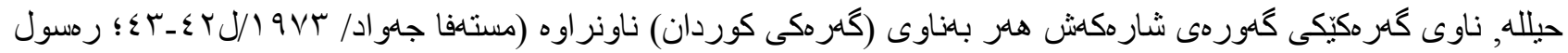

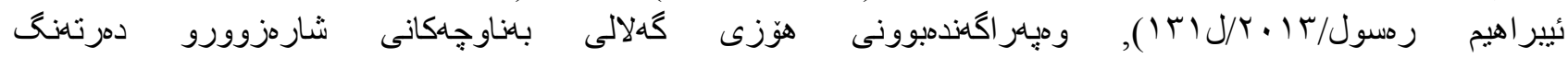

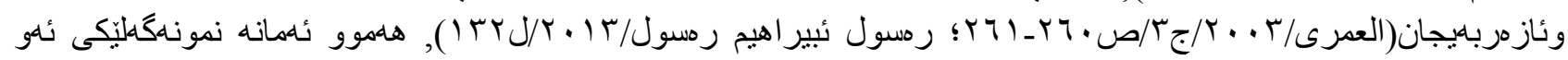

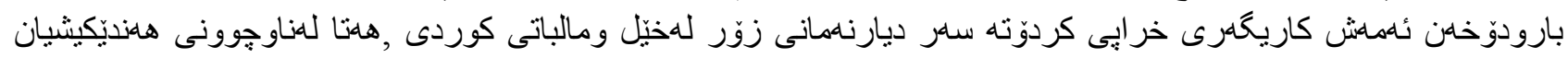

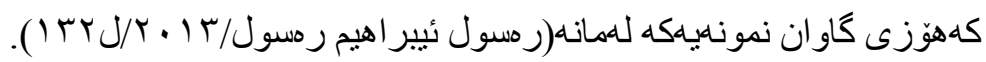

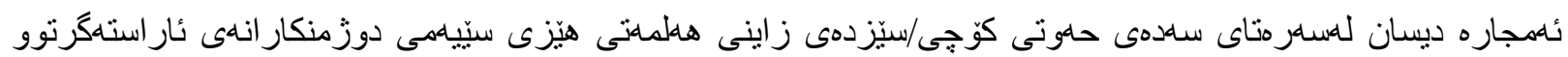

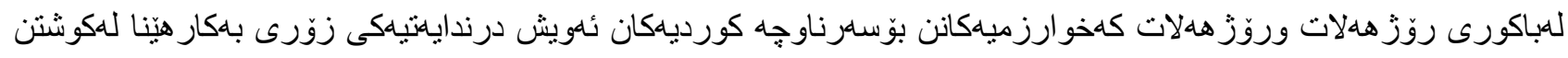

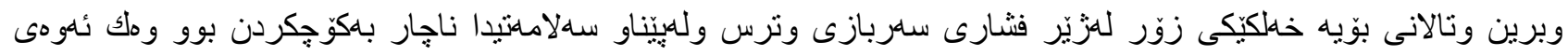

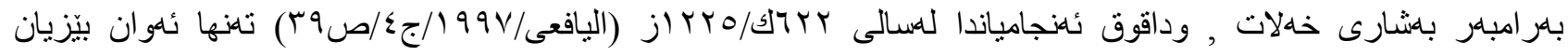

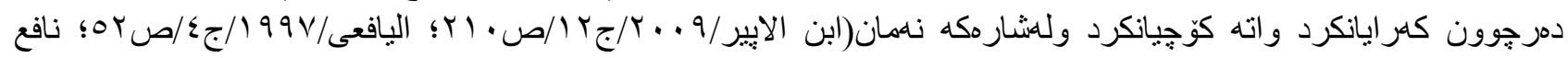

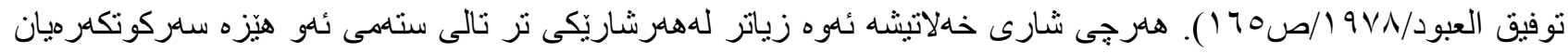

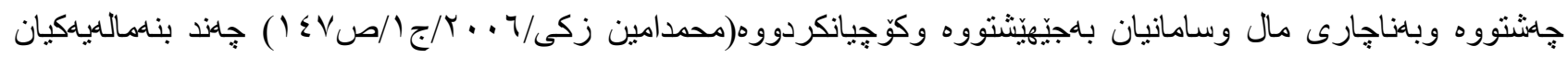




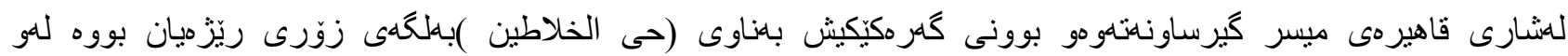

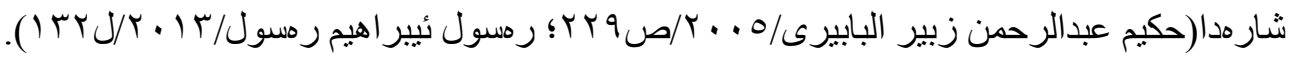

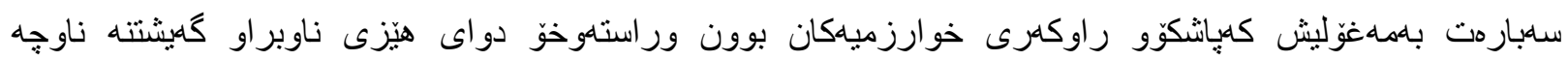

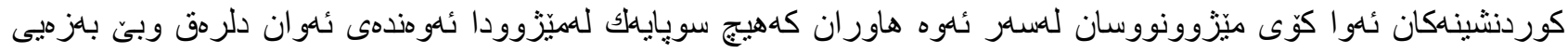

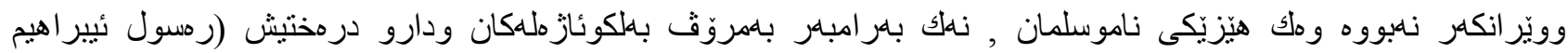

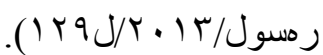

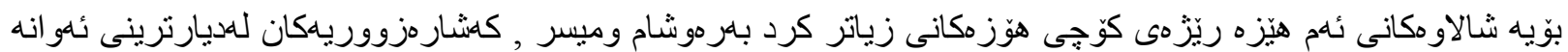

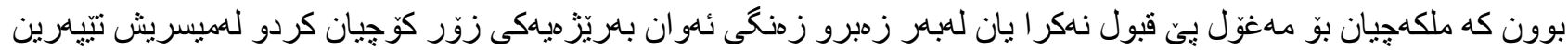

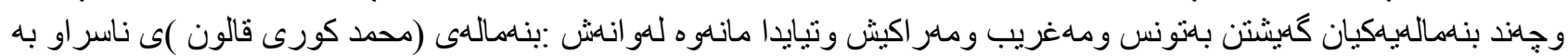

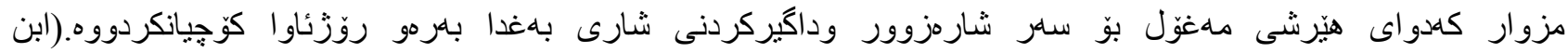

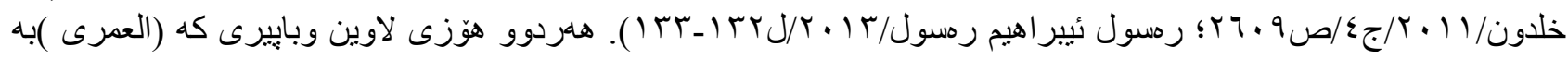

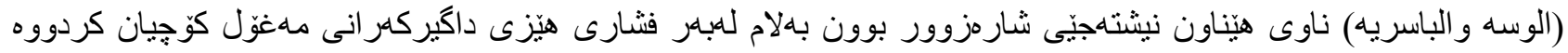

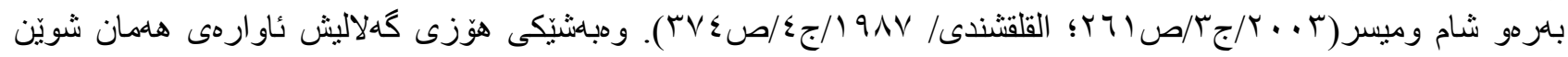

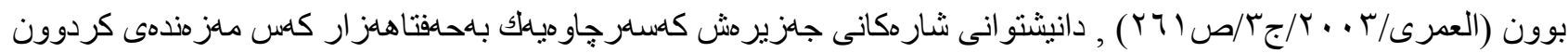

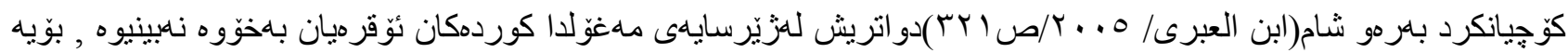

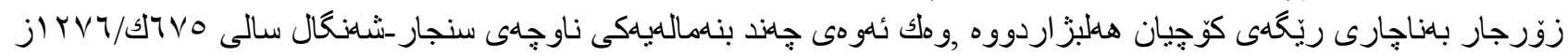

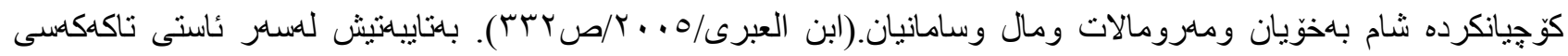

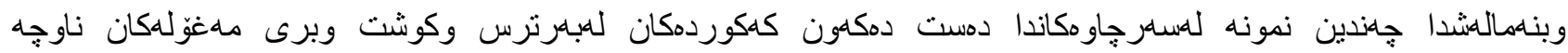

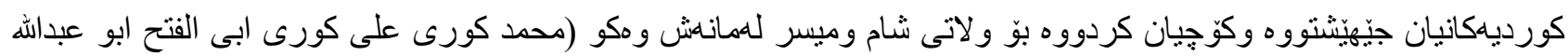

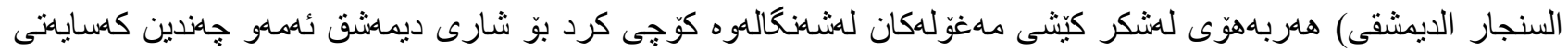

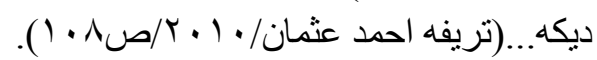

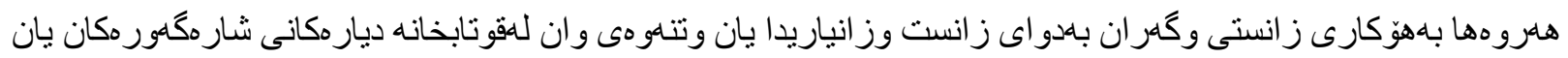

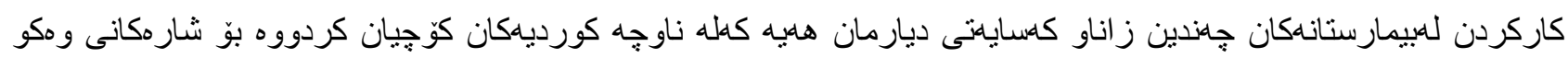

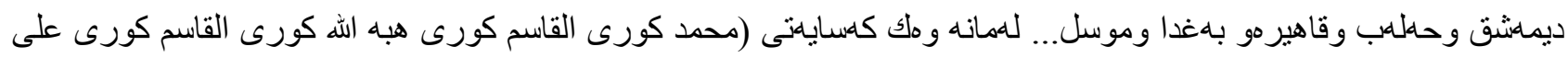

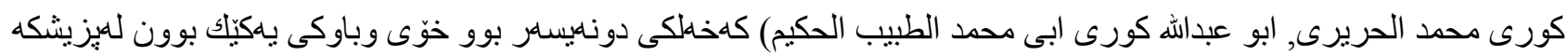

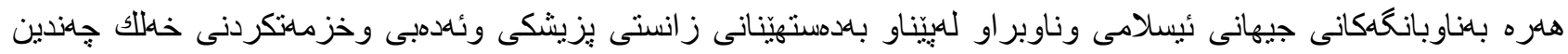

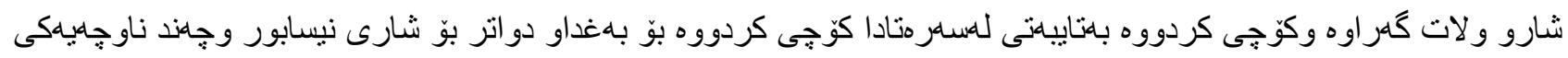

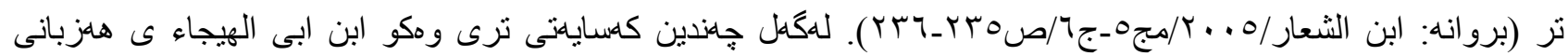

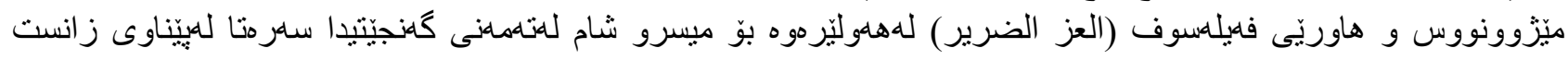

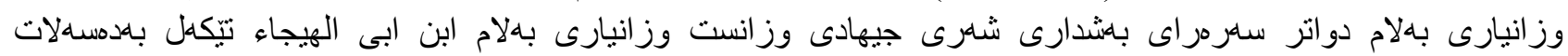

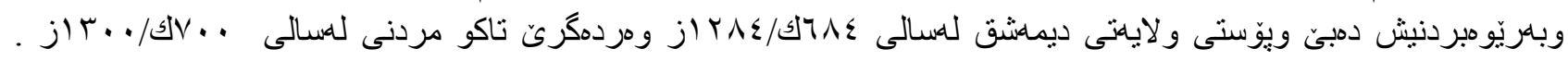

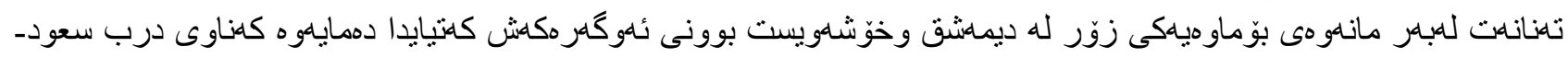

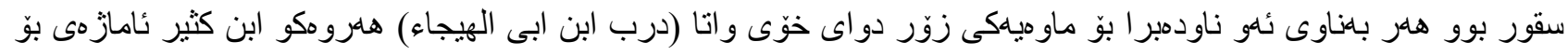

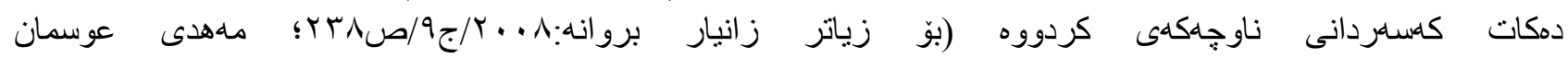

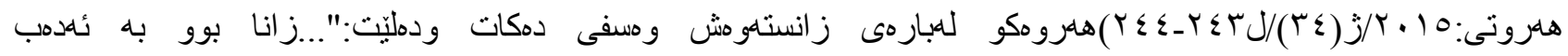

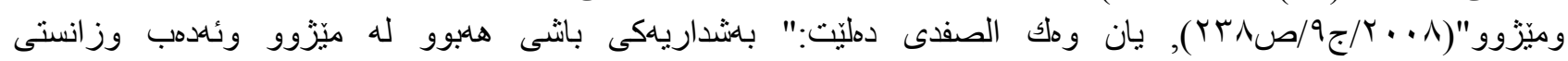

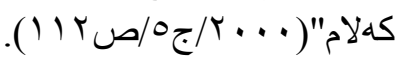

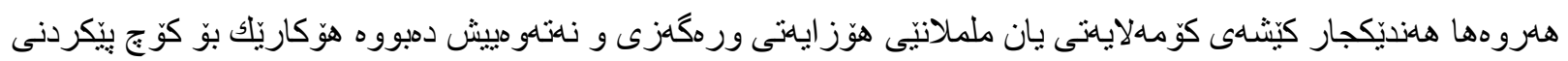

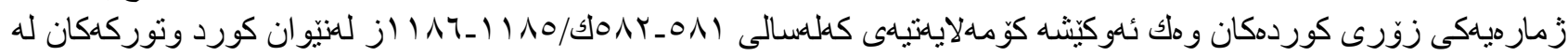

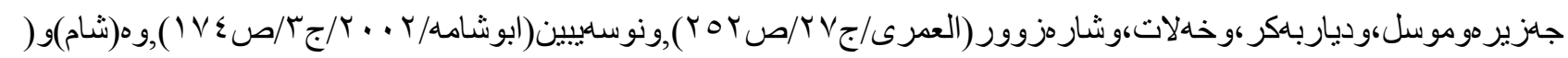

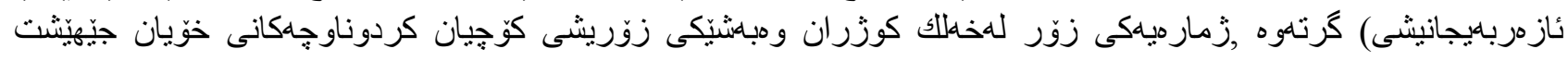

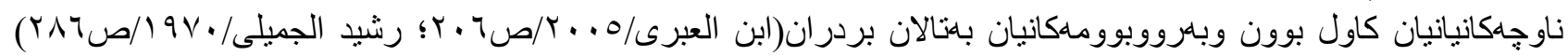




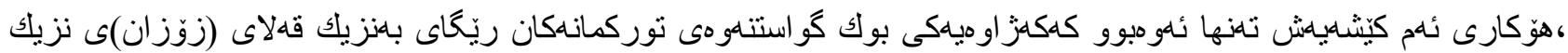

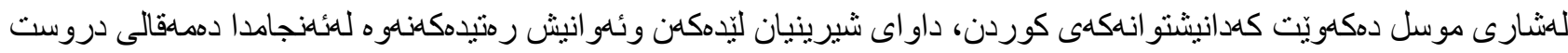

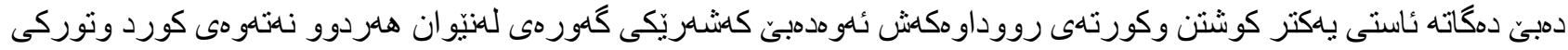

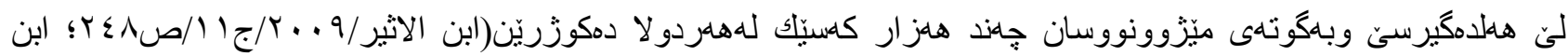

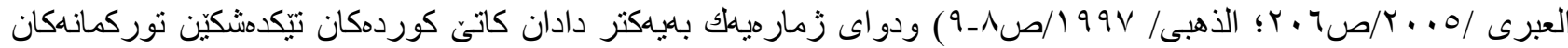

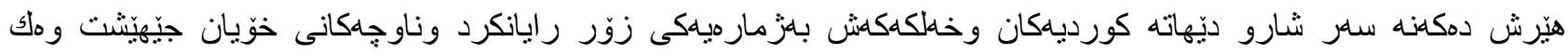

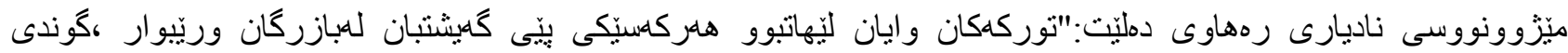

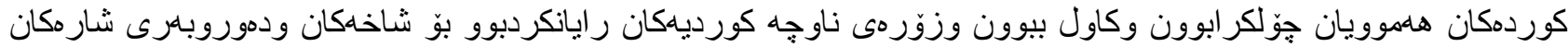

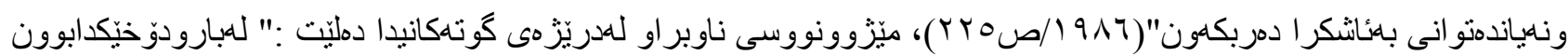

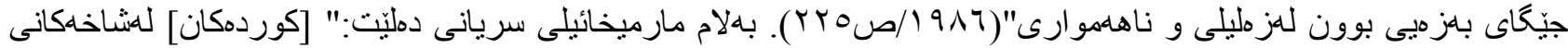

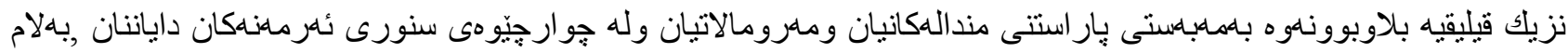

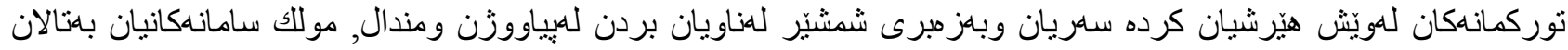

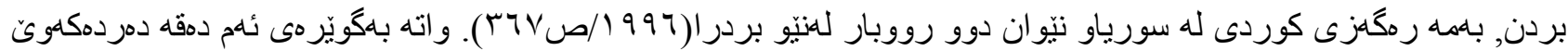

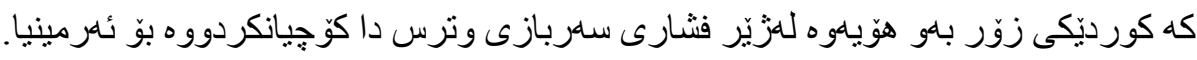

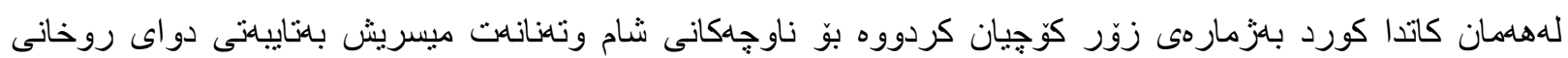

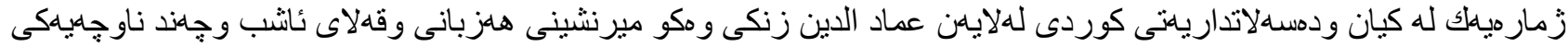

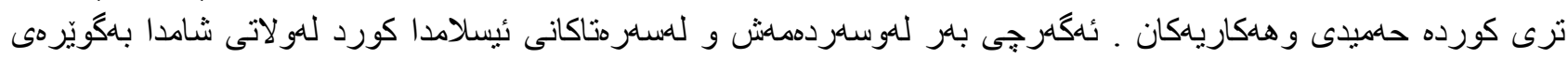

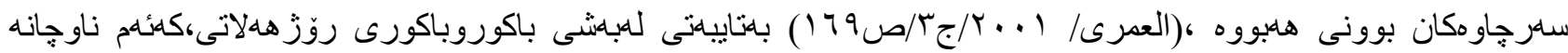

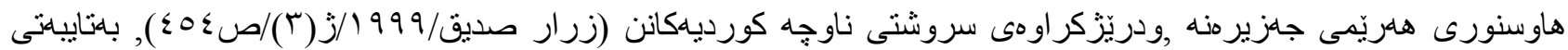

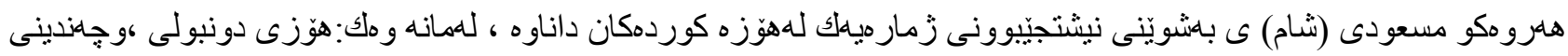

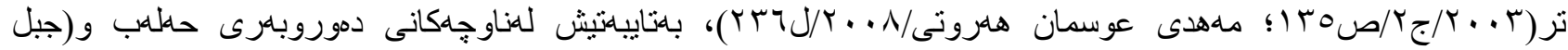

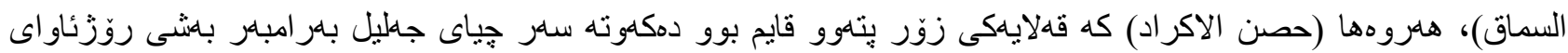

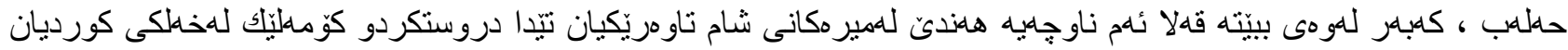

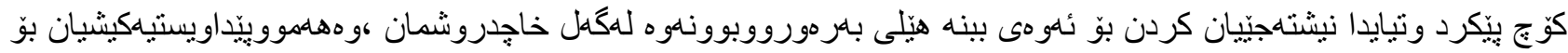

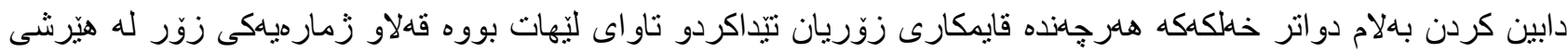

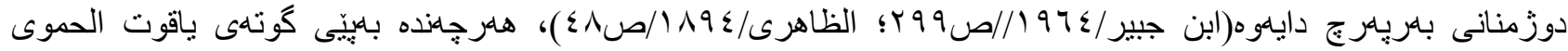

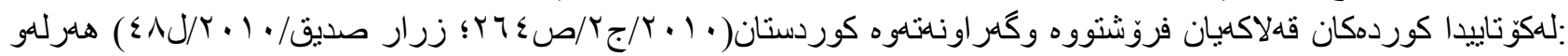

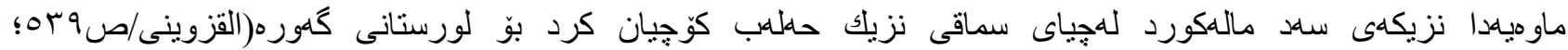

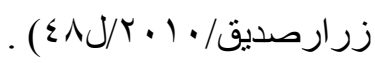

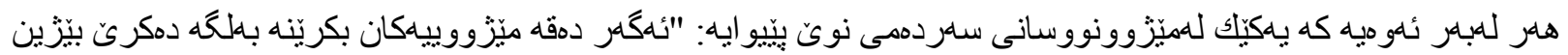

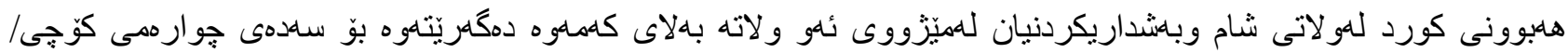

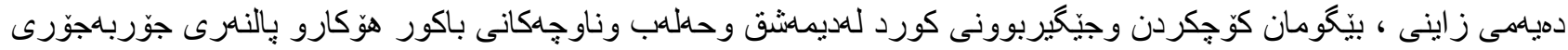

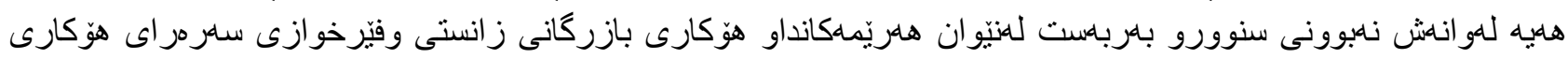

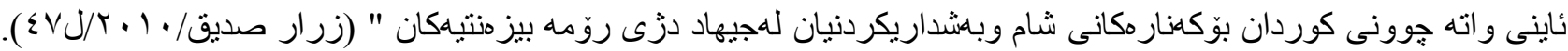

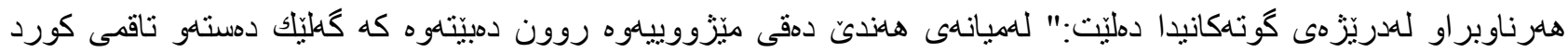

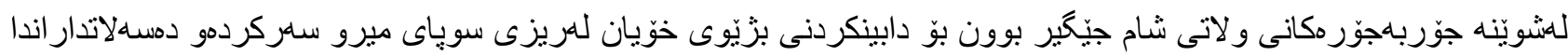

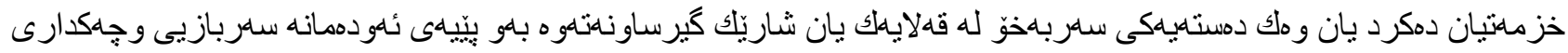

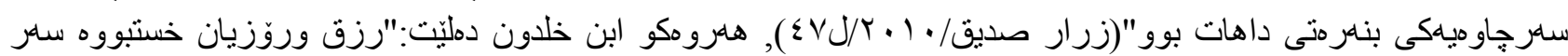

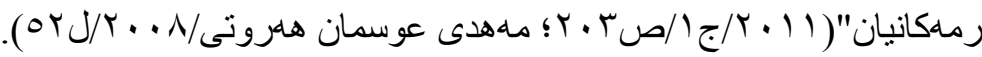

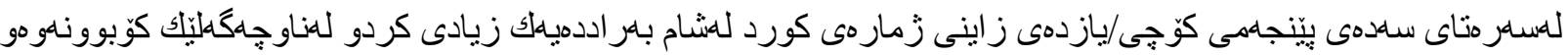

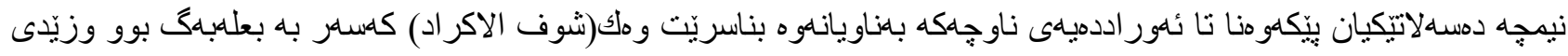

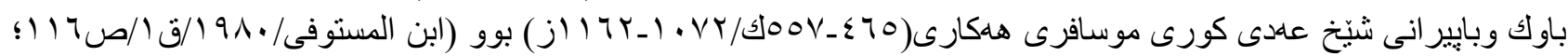




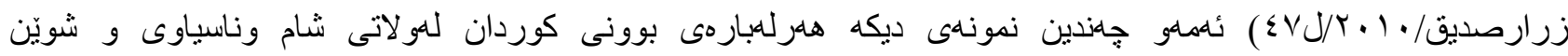

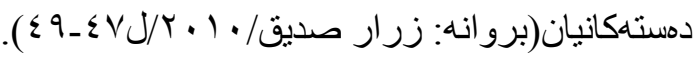

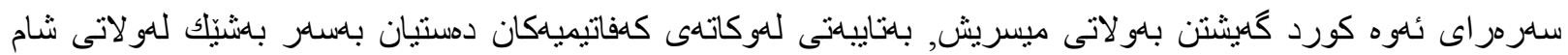

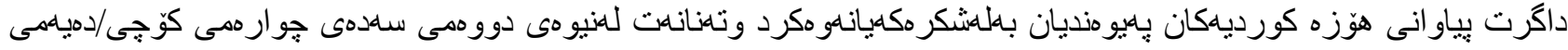

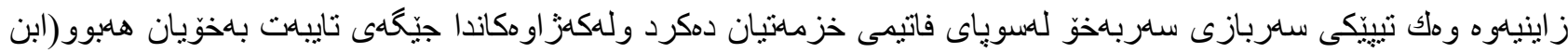

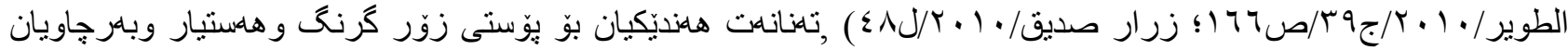

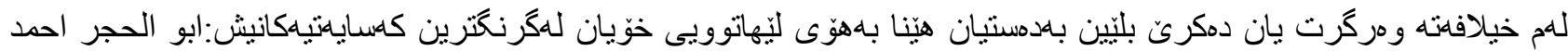

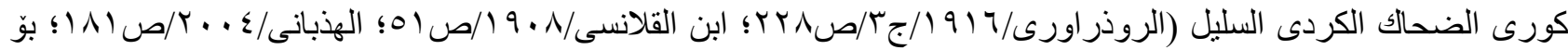

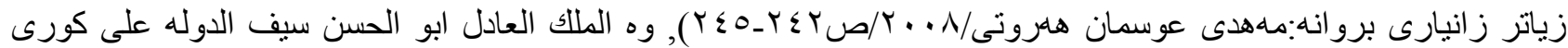

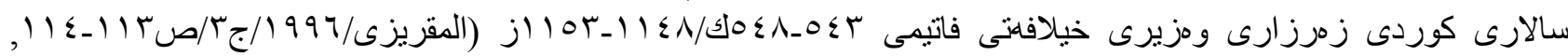

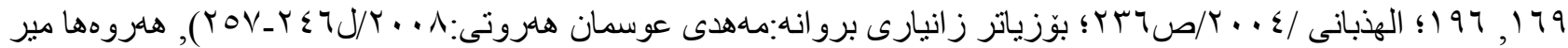

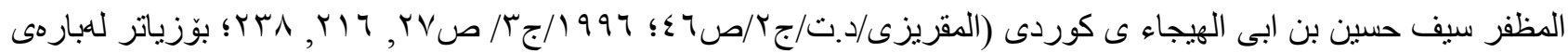

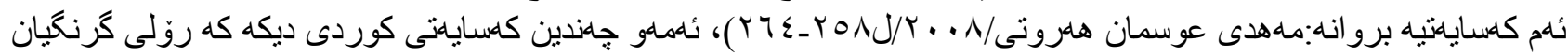

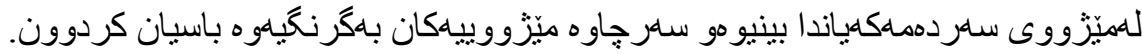

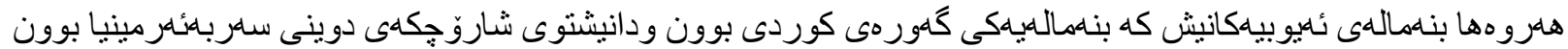

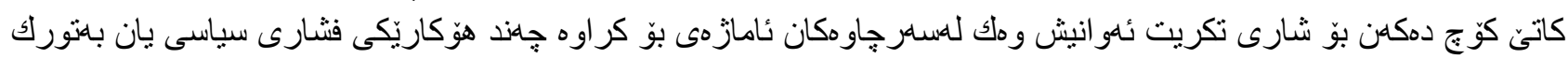

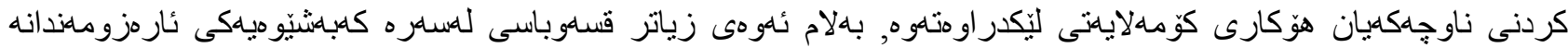

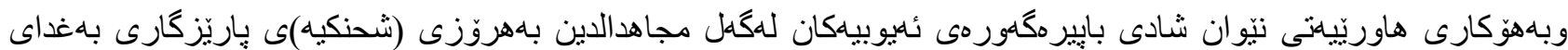

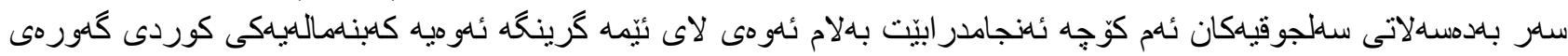

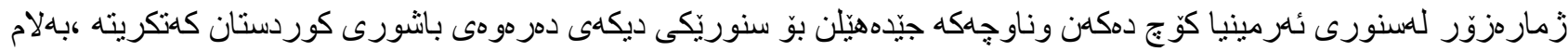

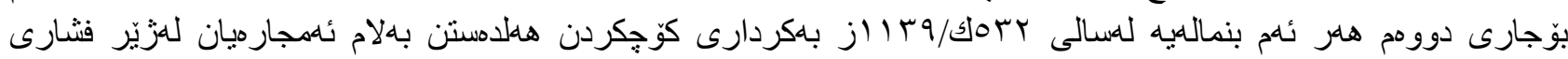

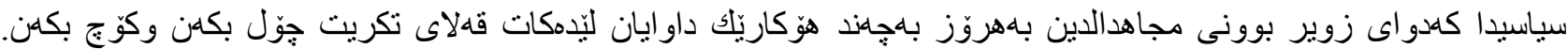

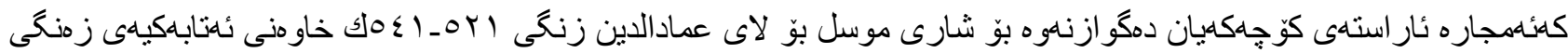

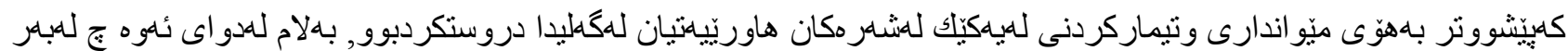

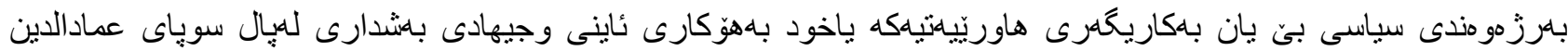

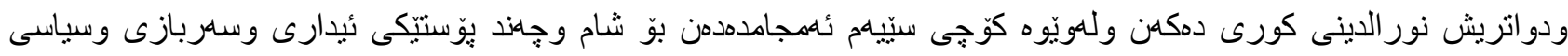

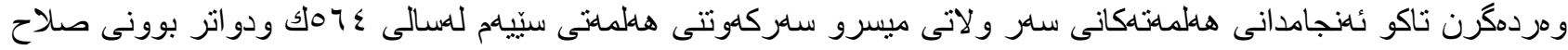

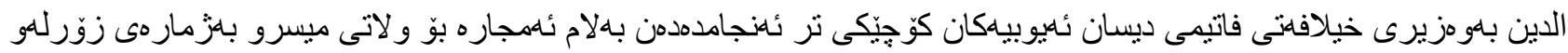

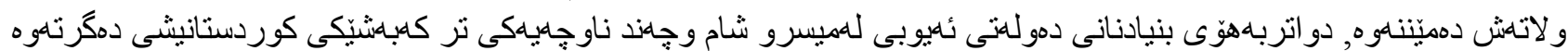

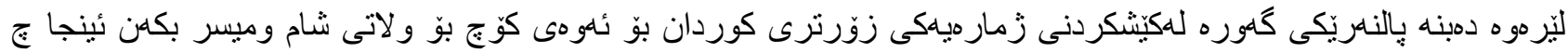

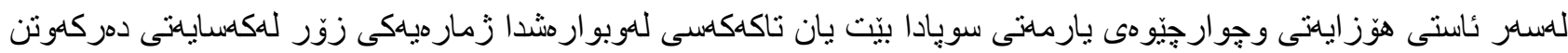

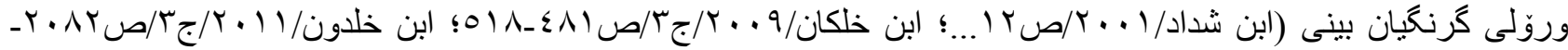

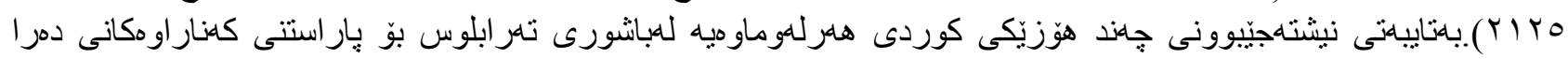

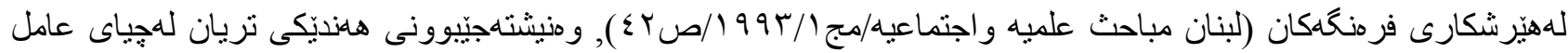

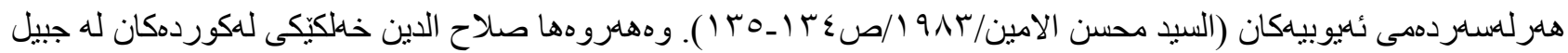

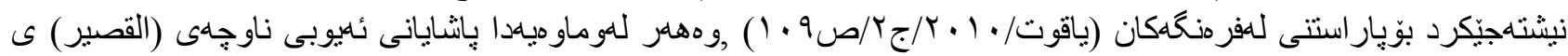

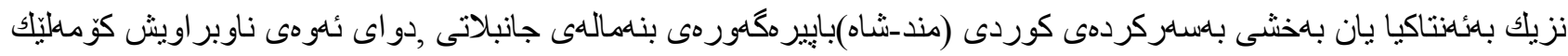

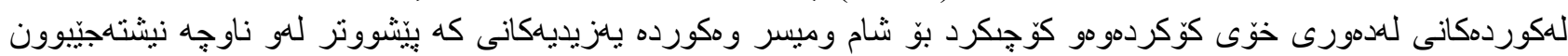

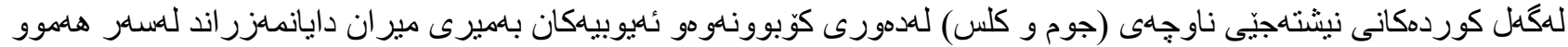

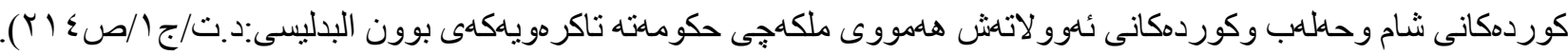

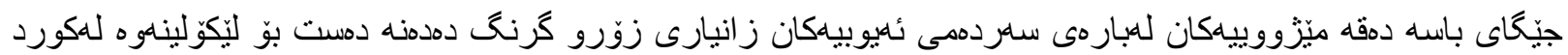

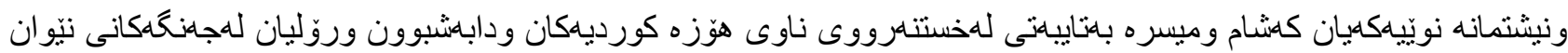

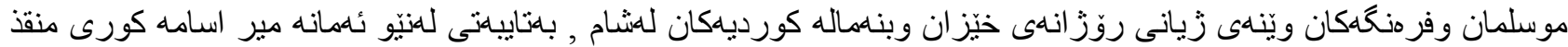


90

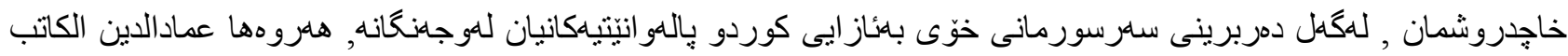

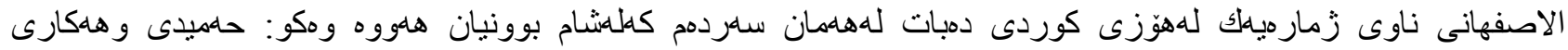

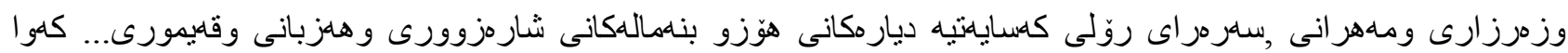

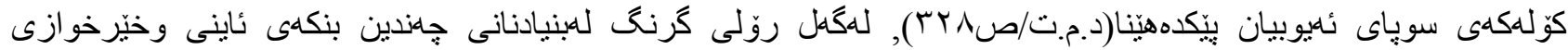

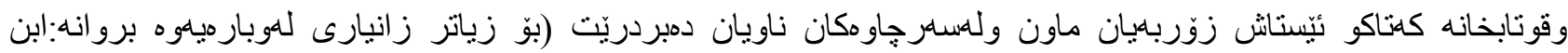

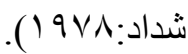

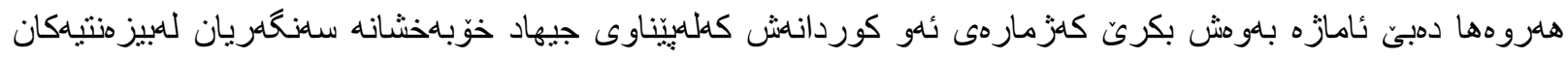

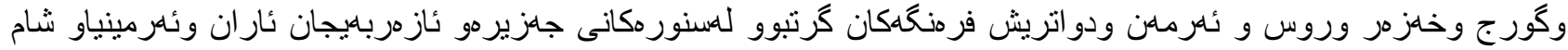

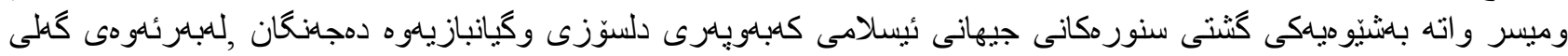

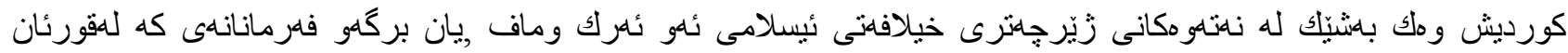

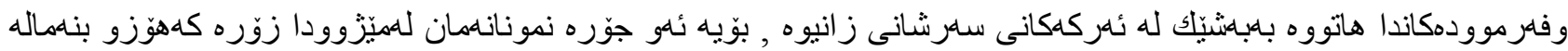

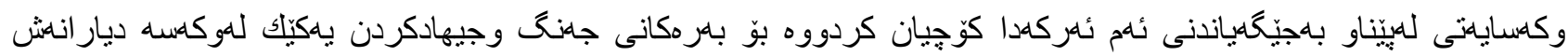

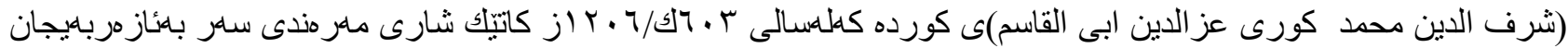

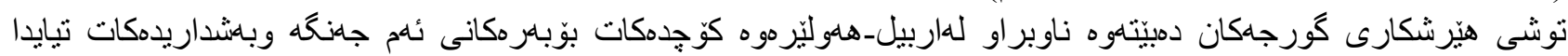

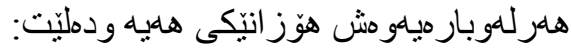

$$
\text { طـان ظلماو اسـرفــوا فى التعدى }
$$

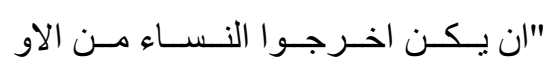

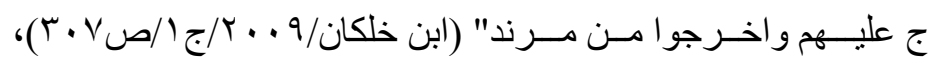

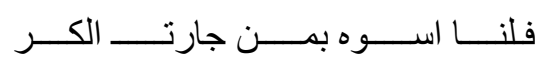

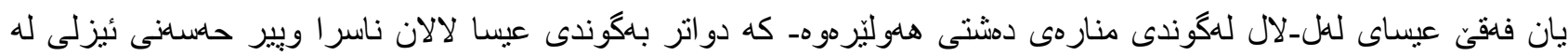

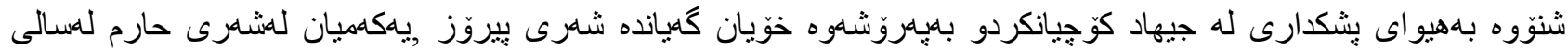

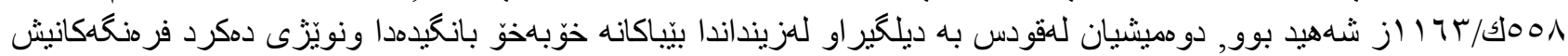

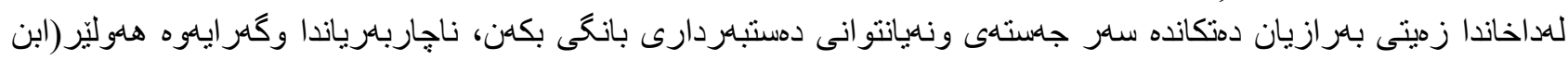

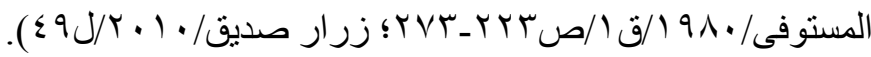

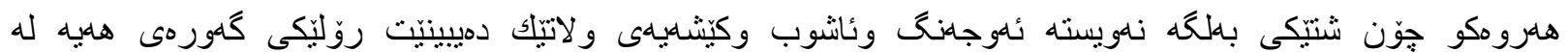

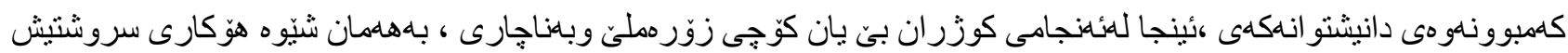

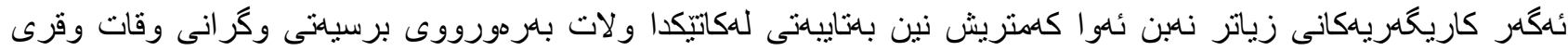

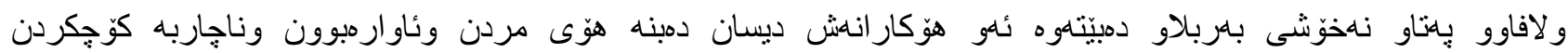

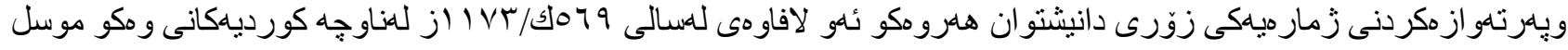

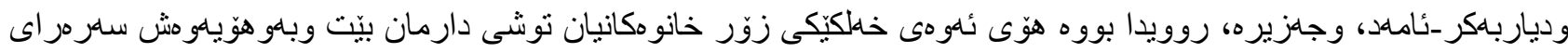

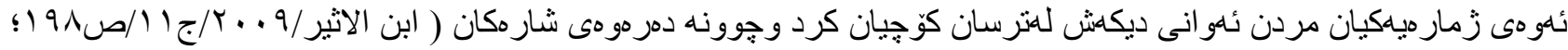

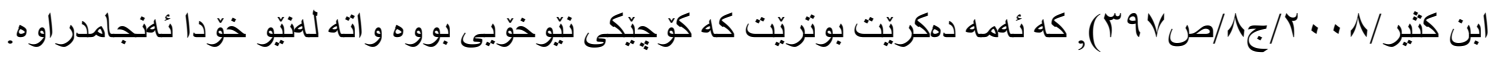

كهليّجار كهقات وقرى وكرانى و وشكهاليش روويدهدا لهيهكياك له وو لاتهكان ودهبووه دياردهيهكى كثتخيرو بلاو

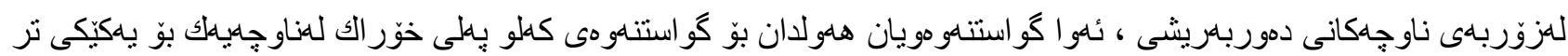

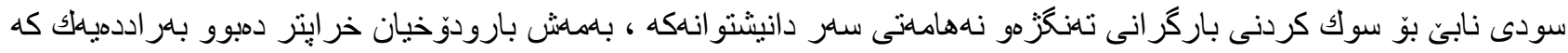

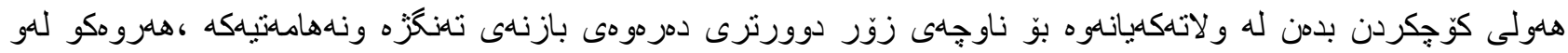

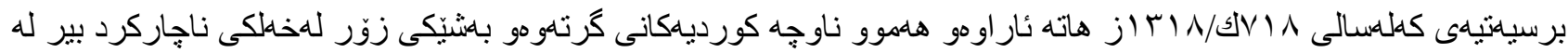

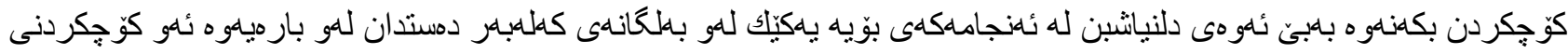

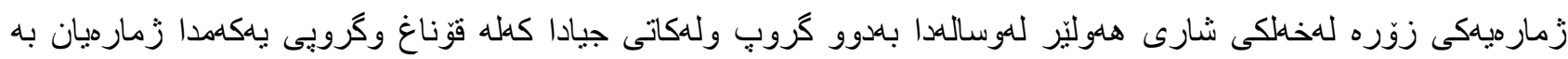

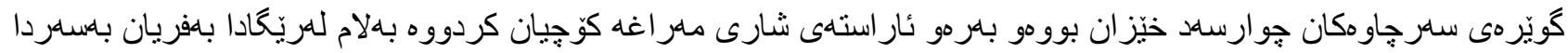

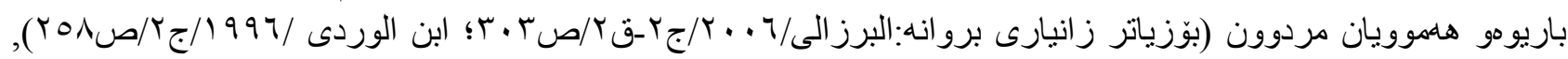

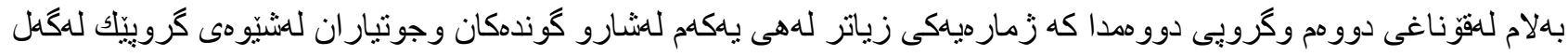




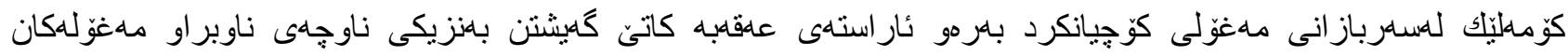

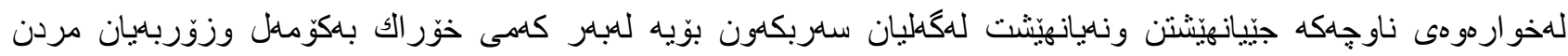

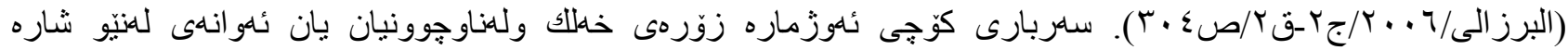

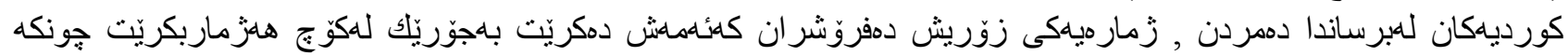

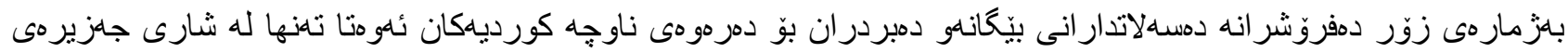

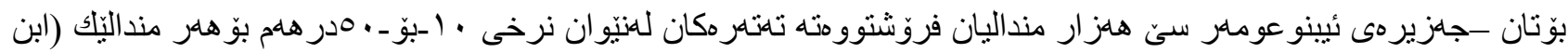

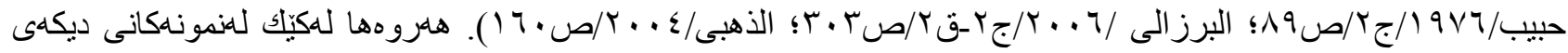

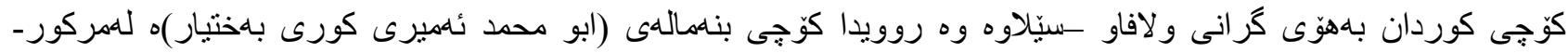

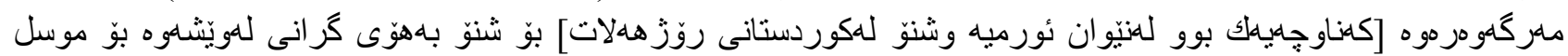

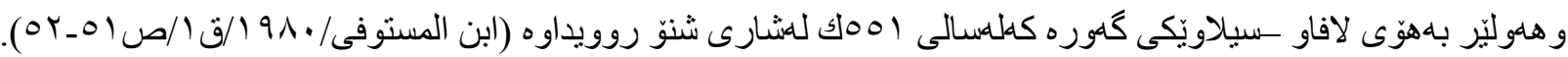

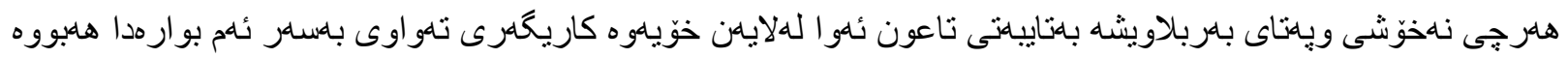

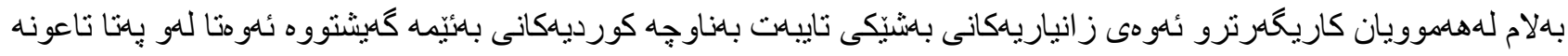

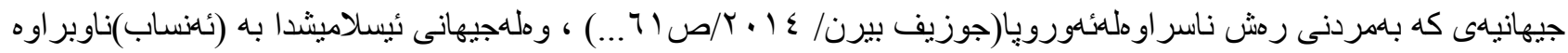

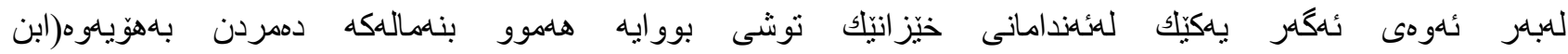

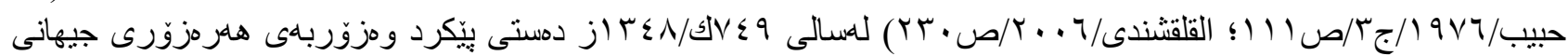

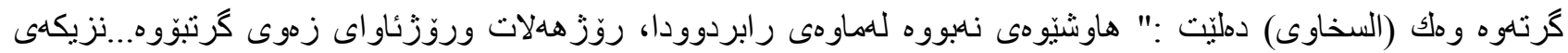

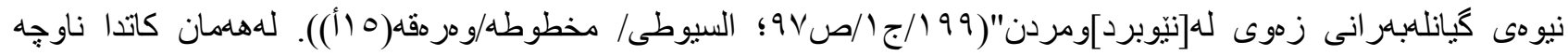

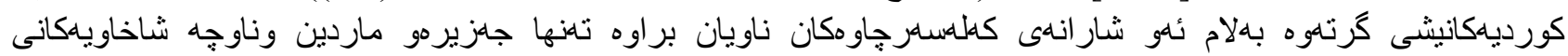

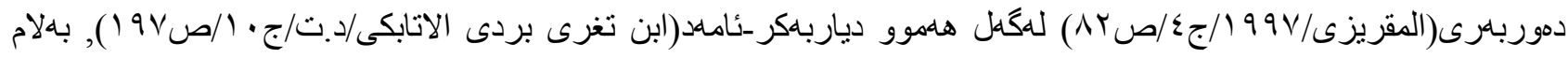

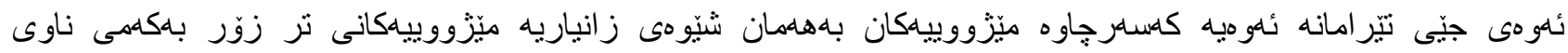

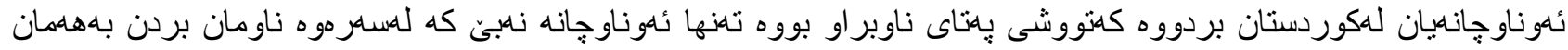

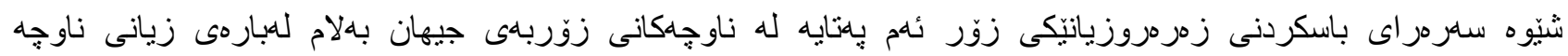

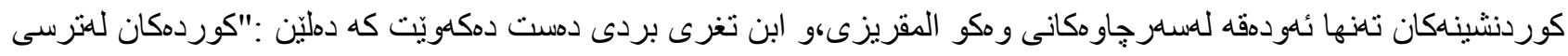

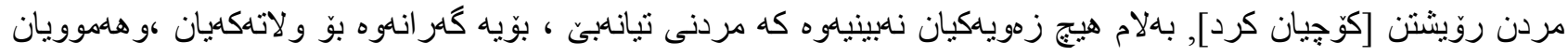

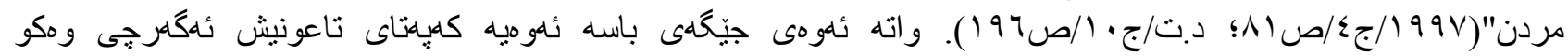

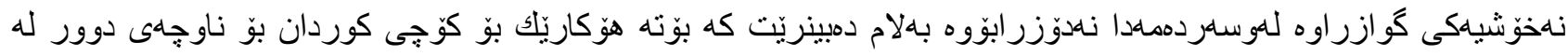

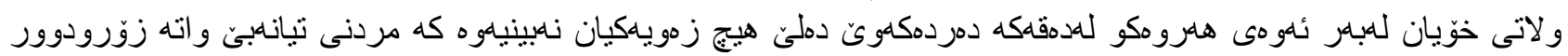

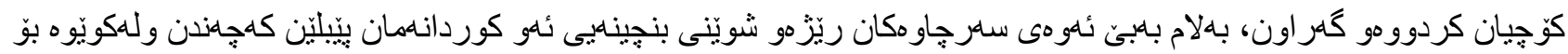

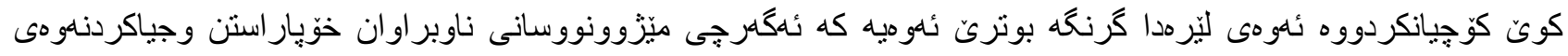

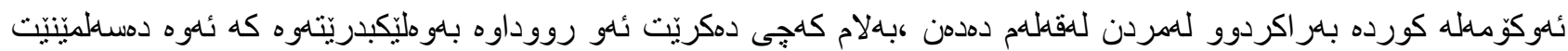

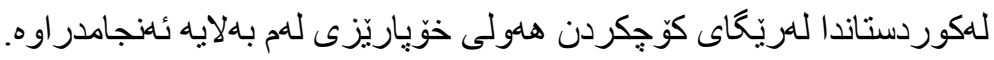

تهو مرهى سيّياهم:دهرئنهنجامهكانى كوّج:-

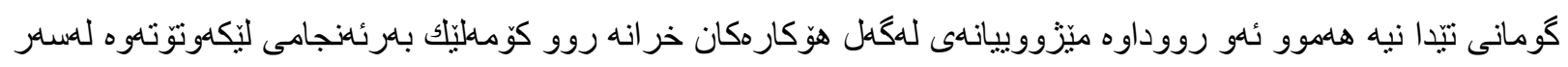

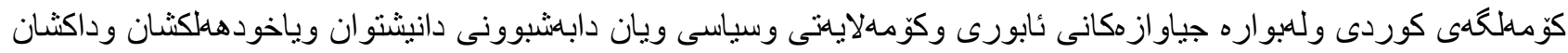

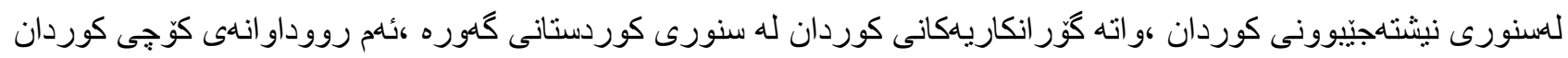

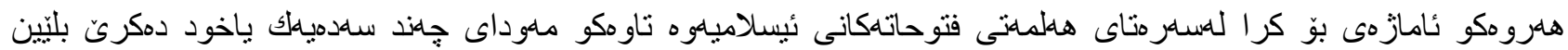




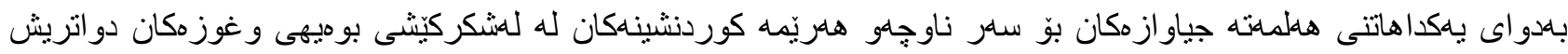

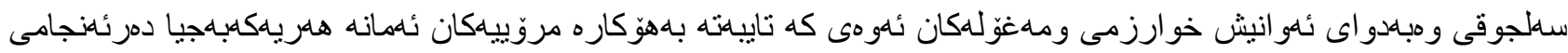

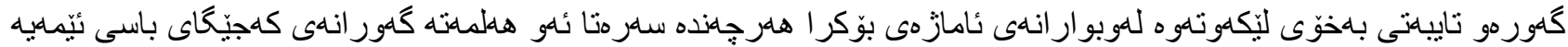

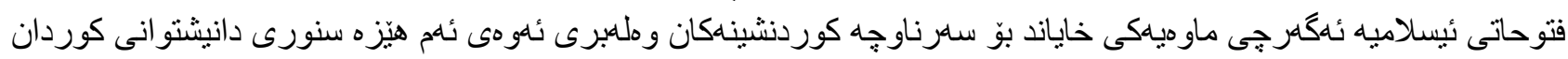

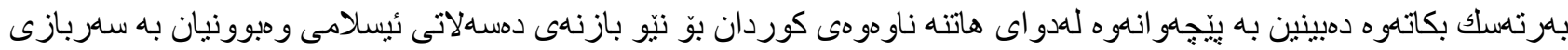

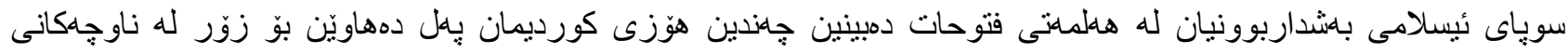

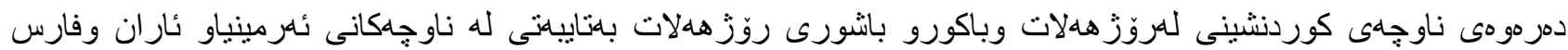

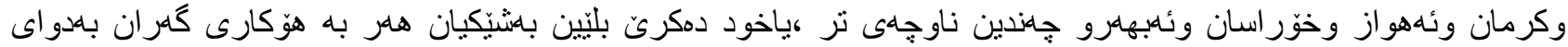

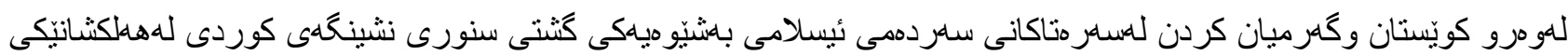

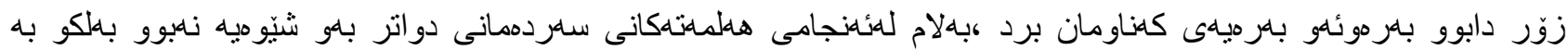

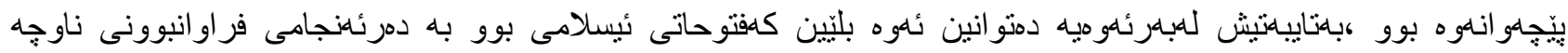

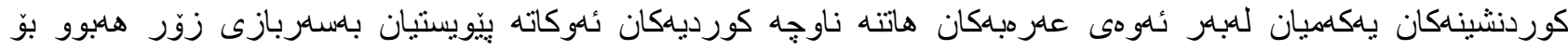

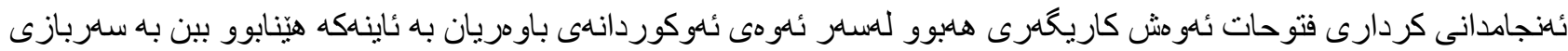

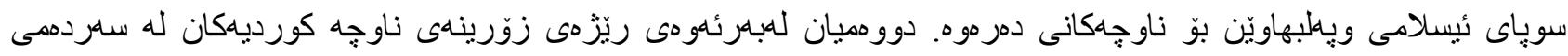

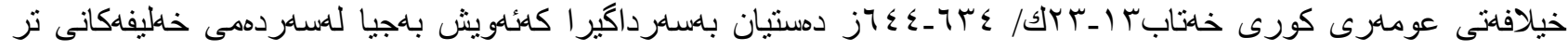

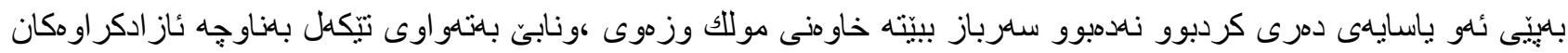

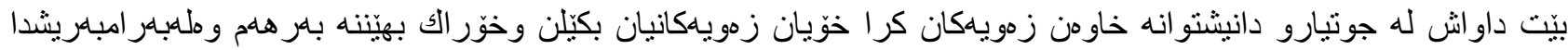

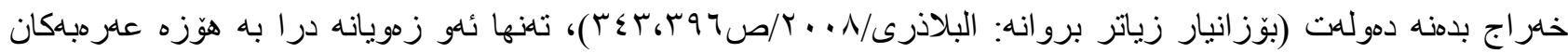

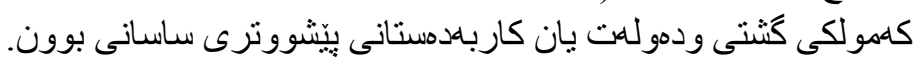

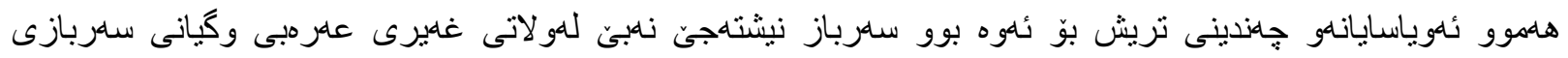

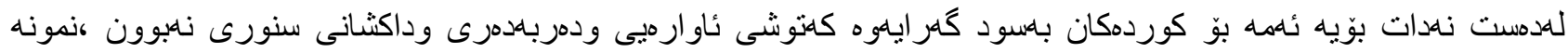

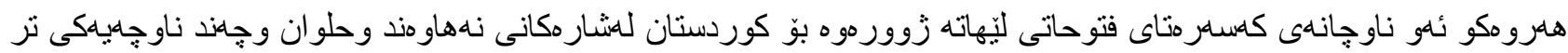

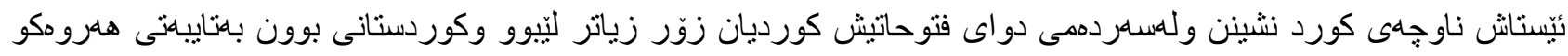

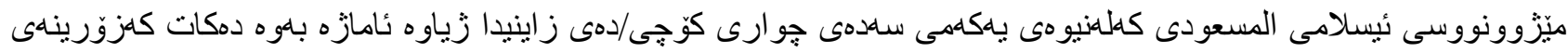

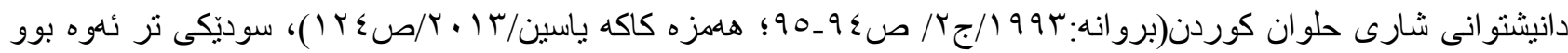

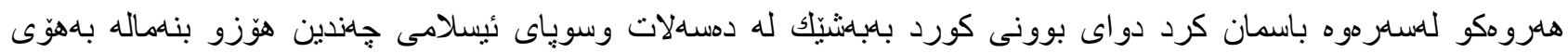

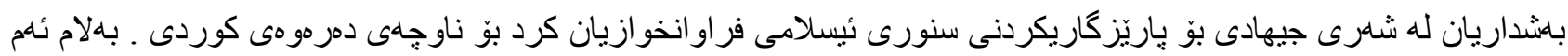

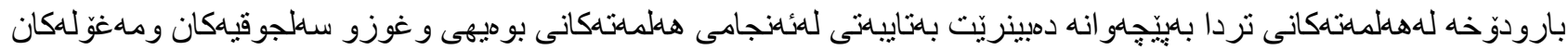

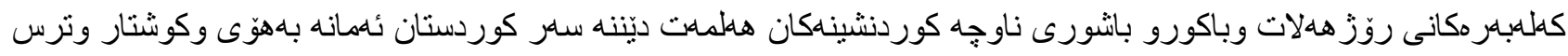

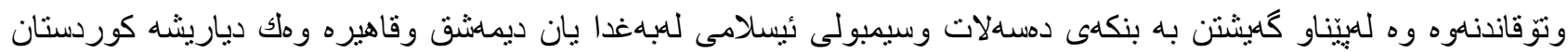

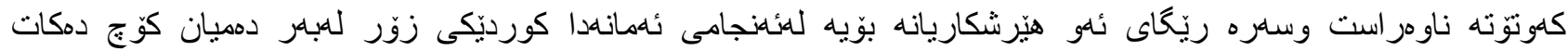

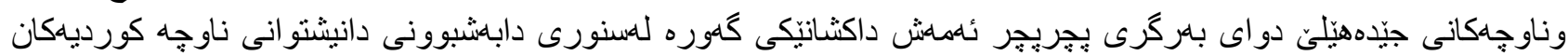

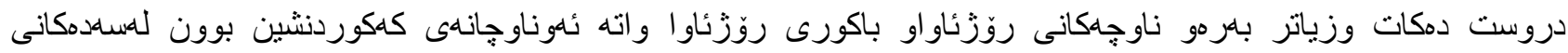

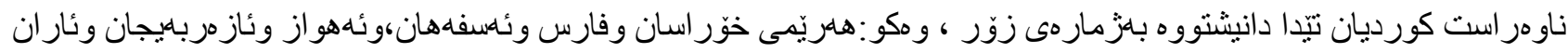

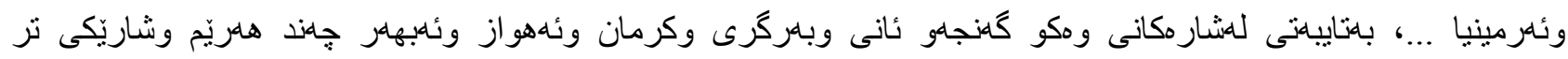

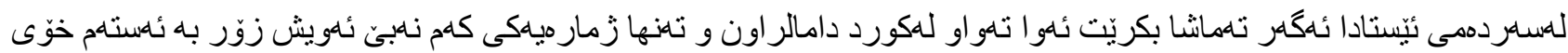

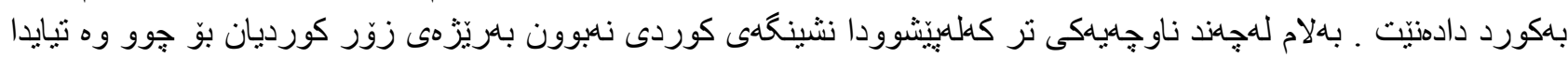

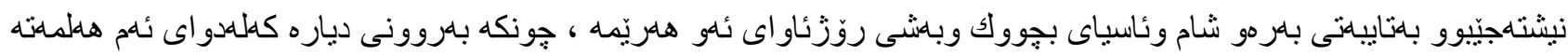

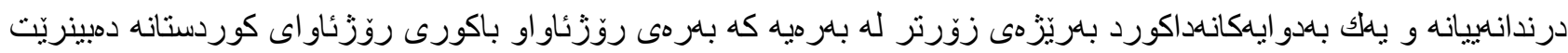

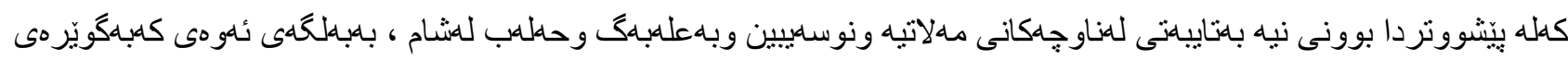

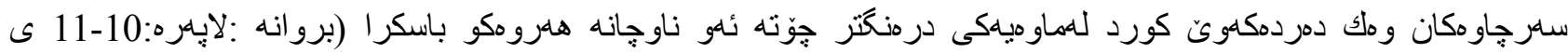

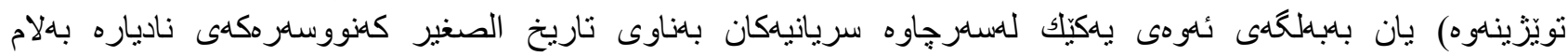

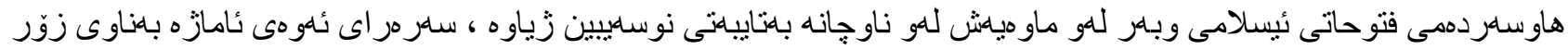

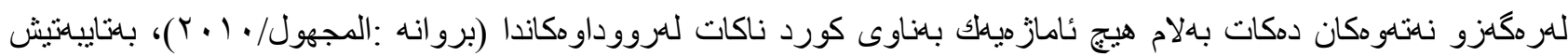




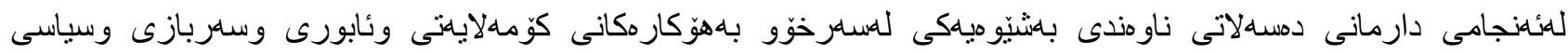

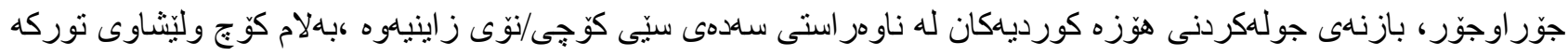

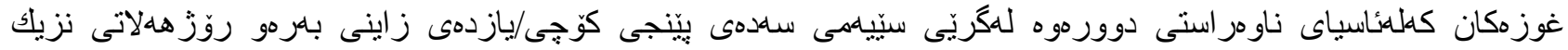

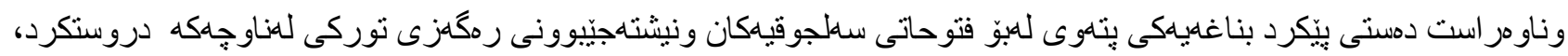

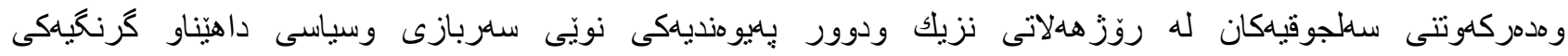

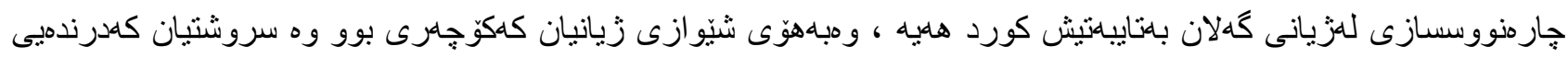

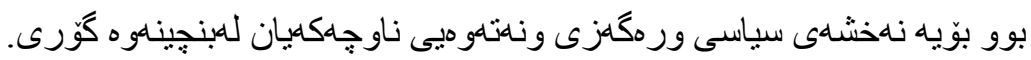

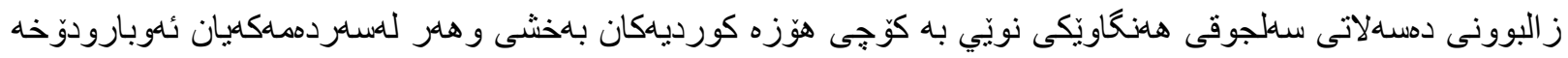

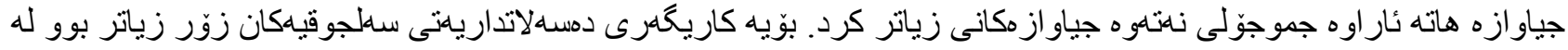

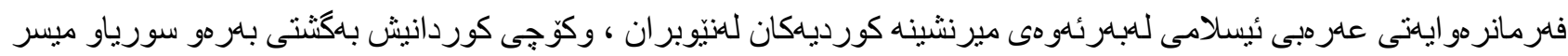

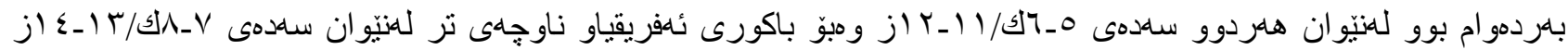

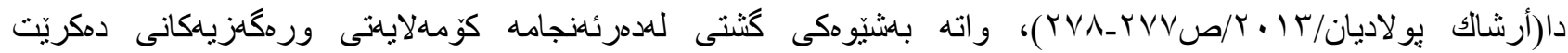

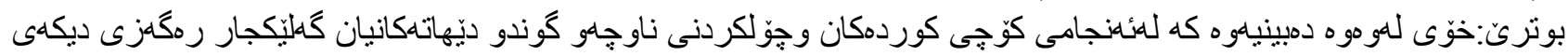

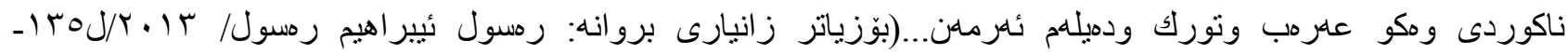

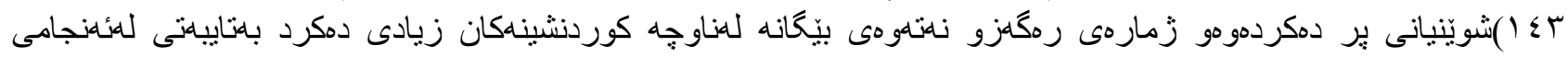

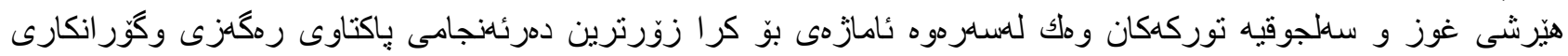

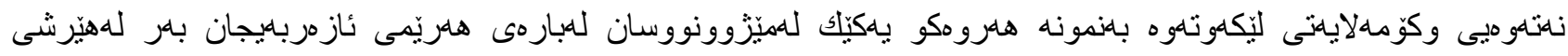

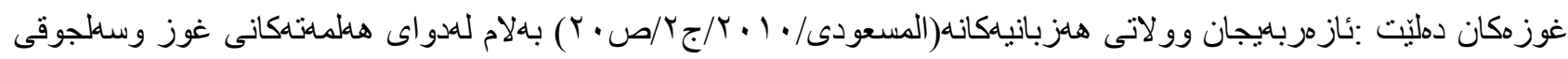

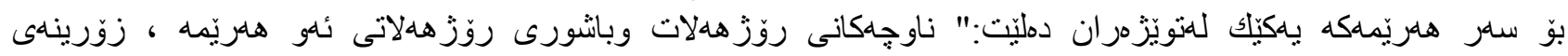

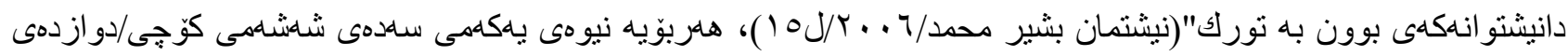

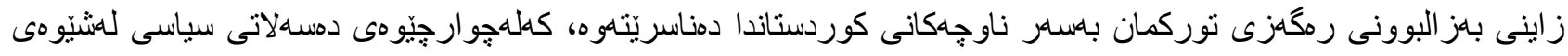

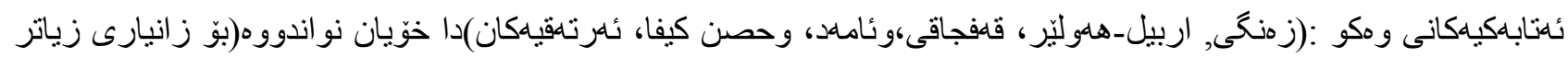

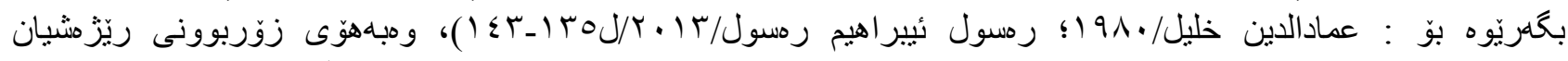

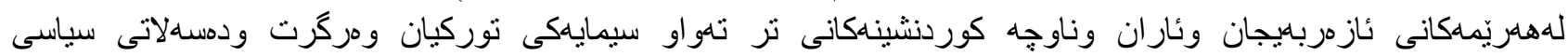

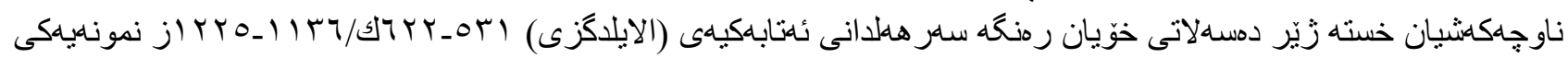

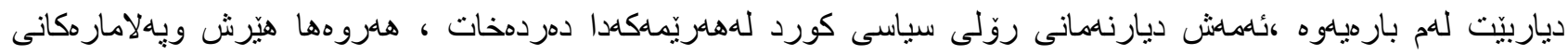

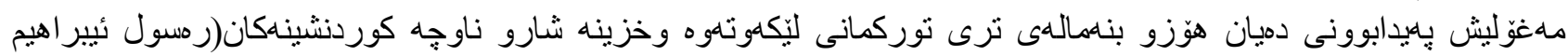

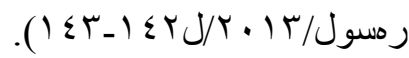

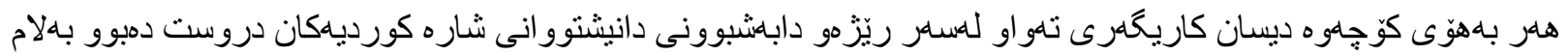

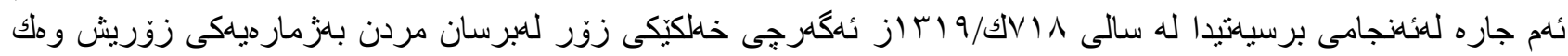

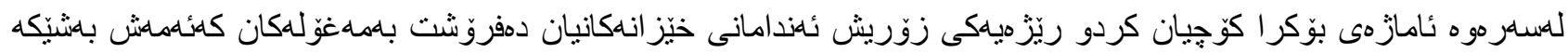

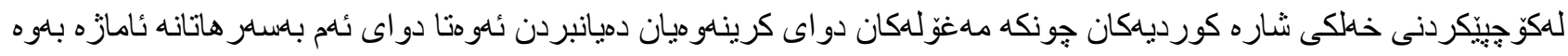

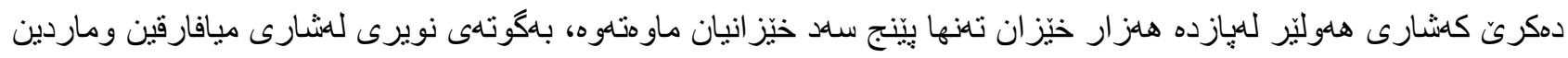

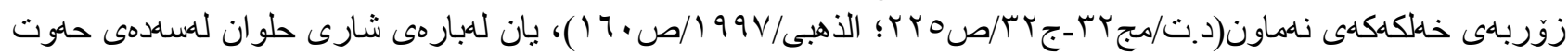

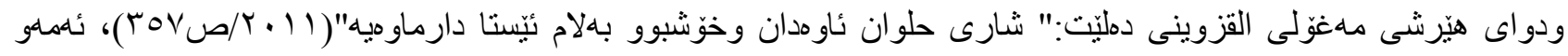

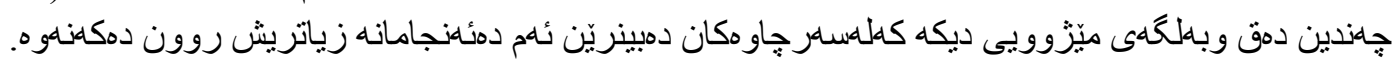

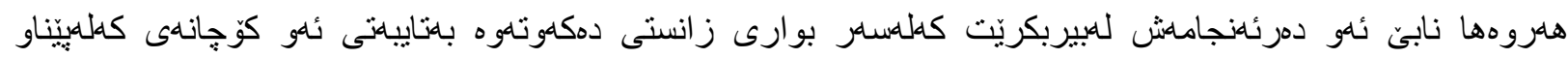

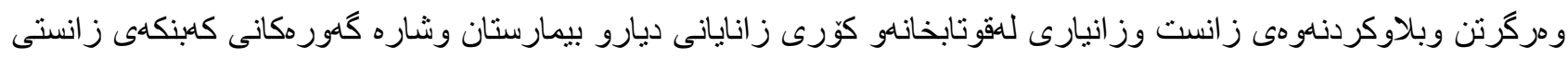

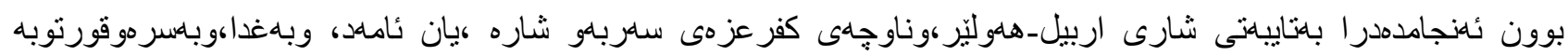

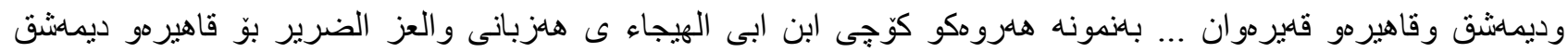

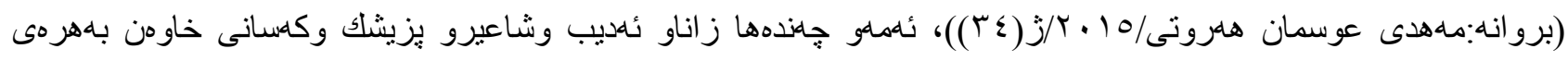

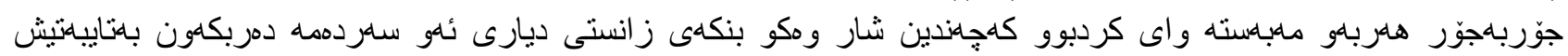

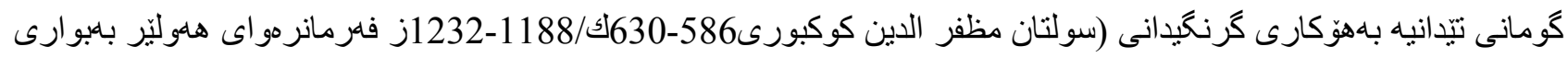




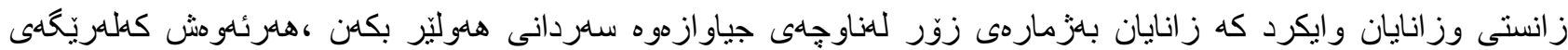

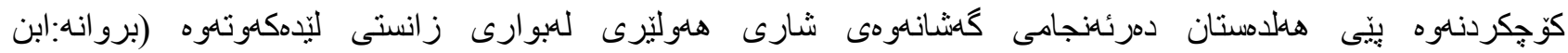

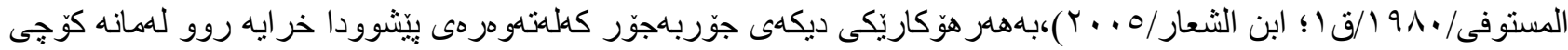

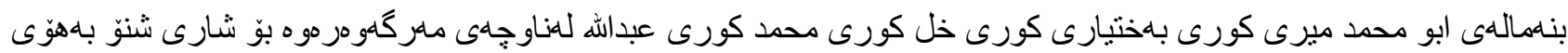

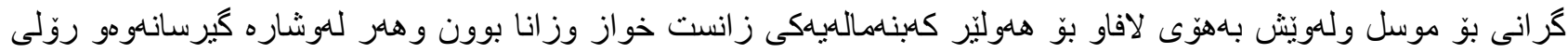

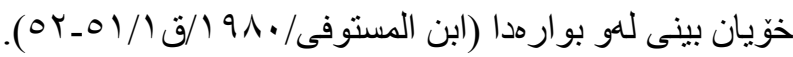

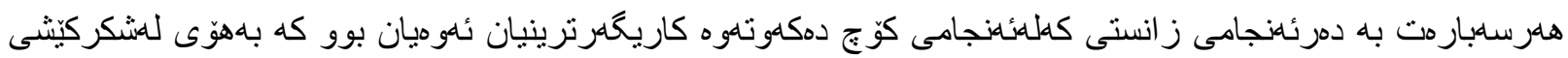

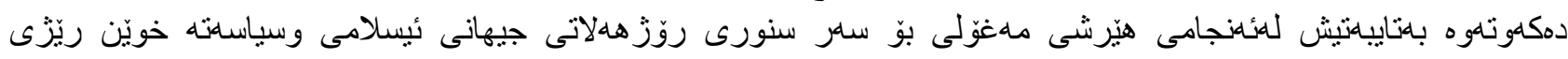

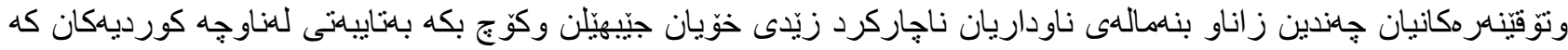

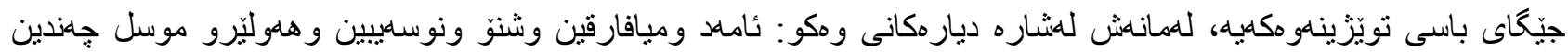

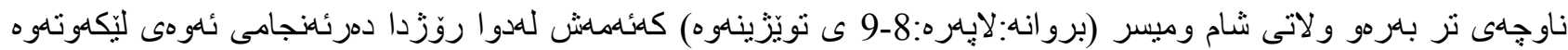

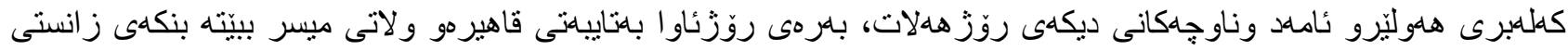

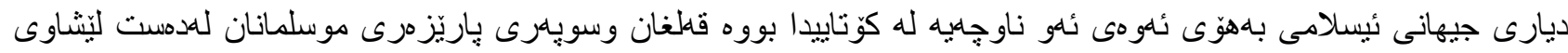

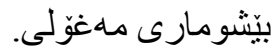

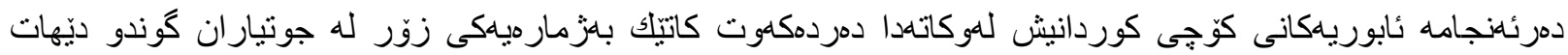

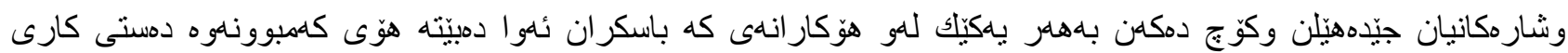

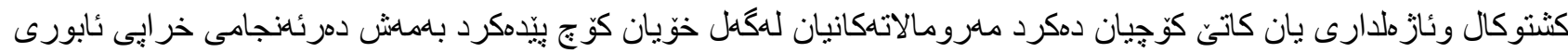

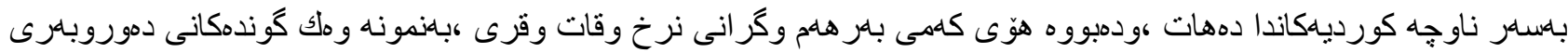

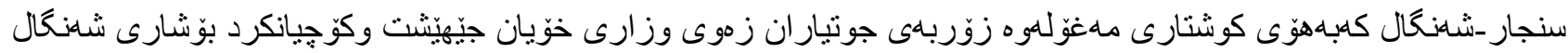

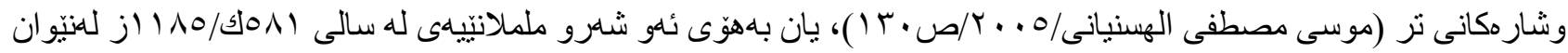

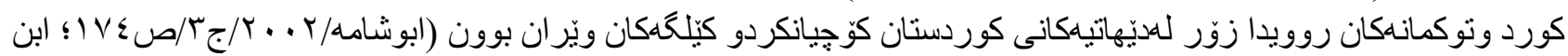

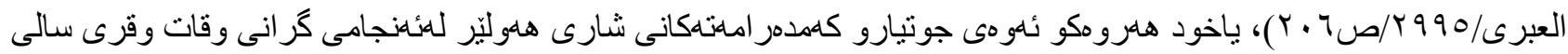

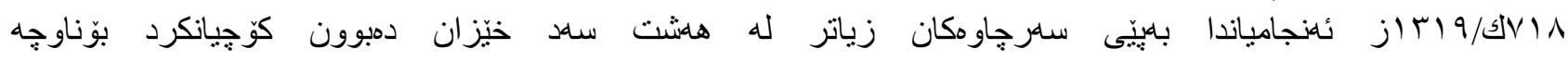

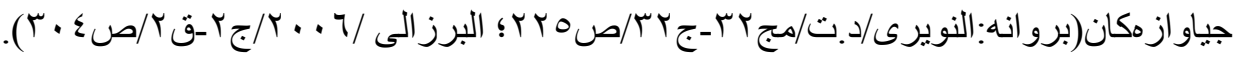

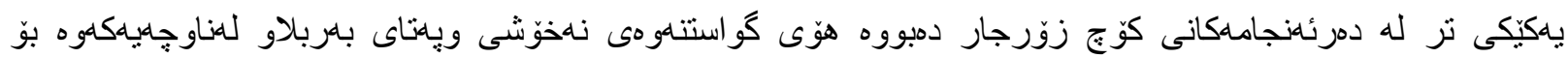

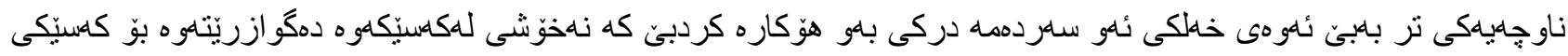

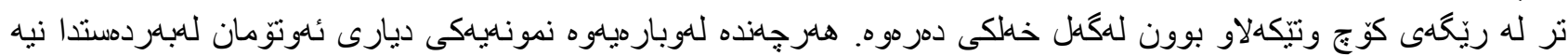

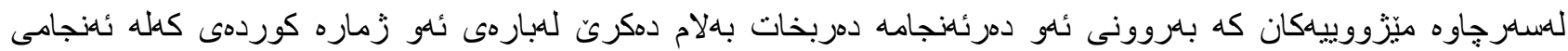

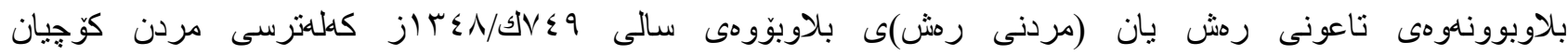

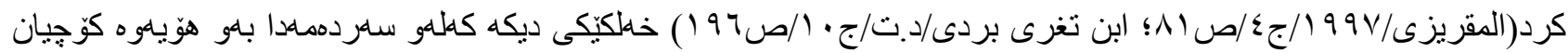

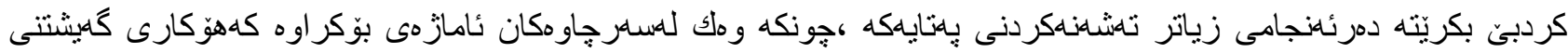

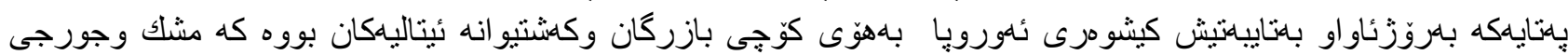

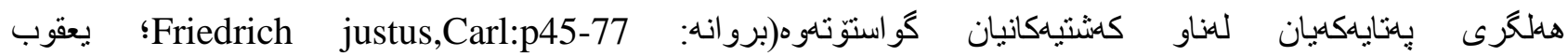

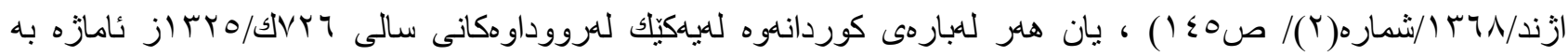

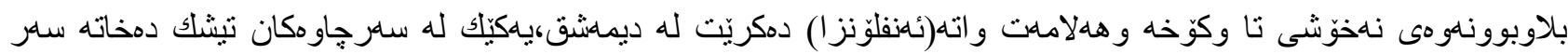

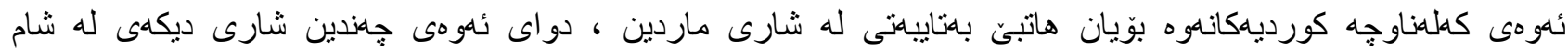

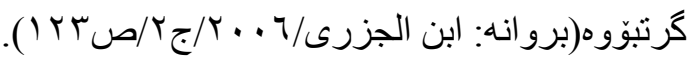

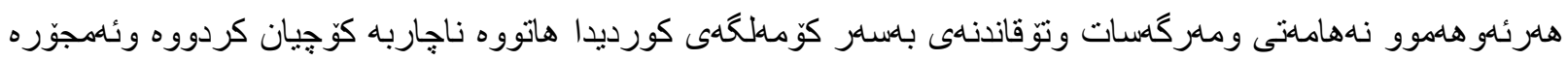

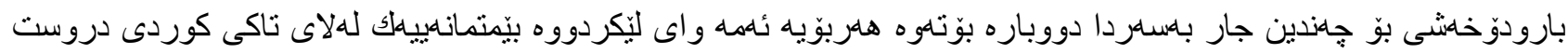

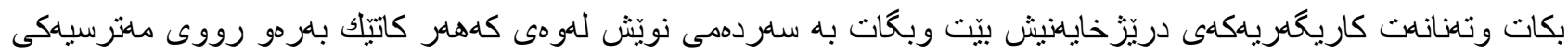

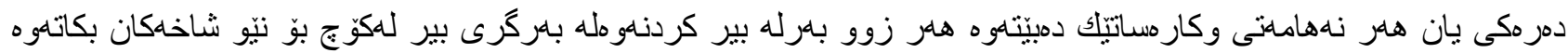

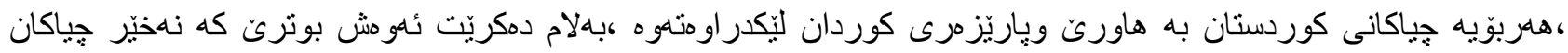




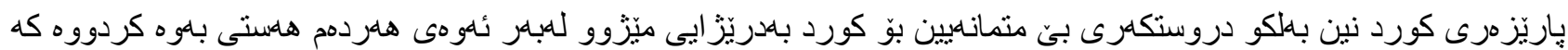

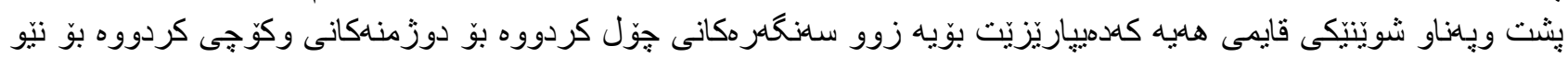

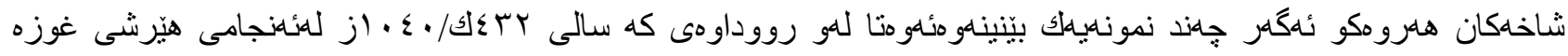

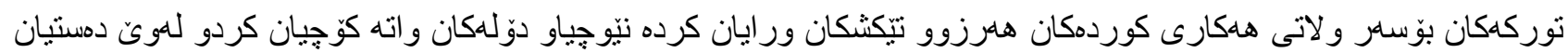

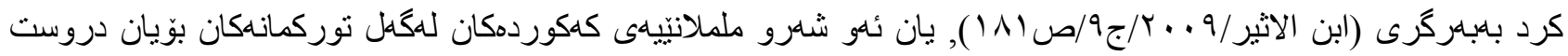

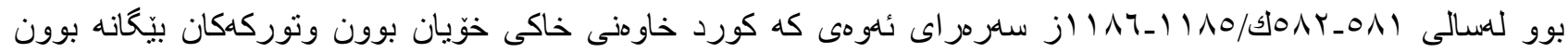

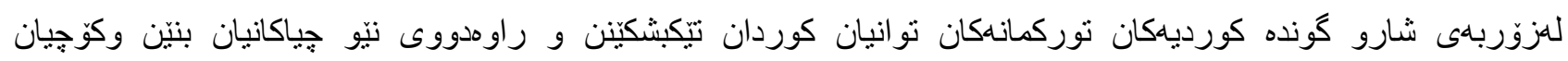

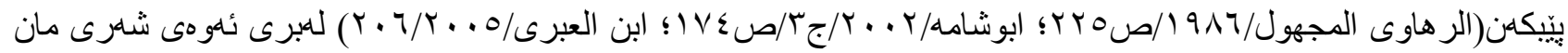

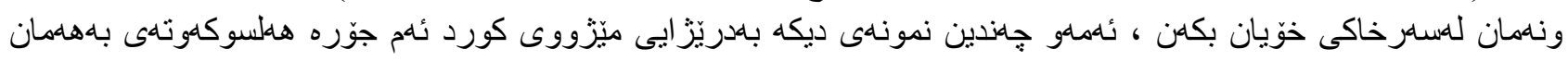

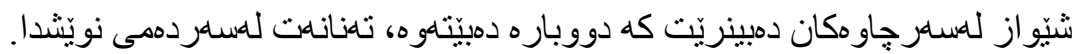


ليستى سمرجاوهكان

$$
\text { الديوستتووس: }
$$

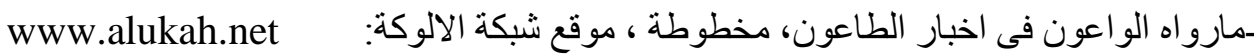

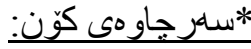

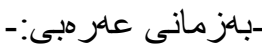

$$
\begin{aligned}
& \text { ابن الاثير :على بن ابى الكرم محمد بن محمد بن عبدالكريم بن عبدالواحد الثيبانى الجزرى"ت:630هج/1232م": } \\
& \text { ـ الكامل فى التاريخ، دار صادر ،(بيروت:2009). } \\
& \text { الاصطخرى:ابى اسحاق ابر اهيم بن محمد الفارسى الاصطخرى المعروف بالكرخى"ت: • ـ سهج/ 901": }
\end{aligned}
$$

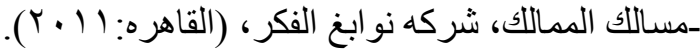

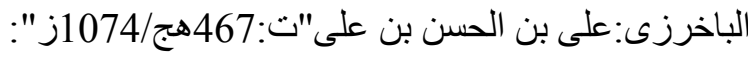
ـالمقتفى على كتاب الروضتين المعروف بتاريخ البرز الى ،تحقيق:عمر عبدالسلام التدمرى، المكتبة العصرية ،شركة ابناء الثريف

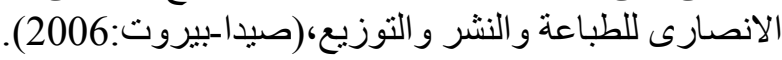
ابن بطوطة:ابو عبداله محمد بن ابر اهيم اللو اتى"ت:779هج/1377م": -رحلة ابن بطوطة أو تحفة النظار فى غرائب الامصار و عجائب الاسفار،دار صادر،ط4،(بيروت:2011).

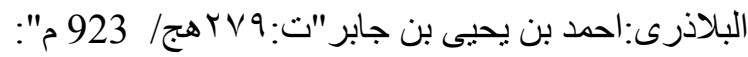

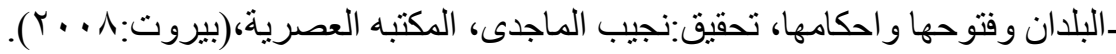
ابن تغرى بردى الاتابكى: جمال الدين ابى المحاسن يوسف "ت:874هج/1469م": ـالنجوم الز اهرة فى ملوك مصر و القاهرة ،مطابع كوستاتسوما وشركاه،(القاهرة:دت). ابن جبير :ابو الحسن محمد بن احمد الكنانى الاندلسى"ت:614هج/1217م": ـتذكرة الاخبار عن اتفاقات الاشعار _المسمى-رحلة ابن جبير ،دار صادر ،(بيروت :1964). ابن الجزرى :شمس الدين ابى عبداله محمد بن ابر اهيم بن ابى بكر القرشى"ت:738هج/1338م": ـتاريخ حوادث الزمان وانبائه ووفيات الاكابر والاعيان من ابنائه ـالمعروف ب-تاريخ ابن الجزرى،تحقيق:عمر عبد السلام التدمرى ،المكتبة العصرية ،(صيدا-بيروت:2006).

$$
\text { ابن حبيب:الحسن بن عمر بن الحسن بن عمر"ت:779 هج/1377م": }
$$

ـنذكرة النبيه فى ايام المنصور وبنيه، تحقيق:محمد محمد امين ،مطبعة دار الكتب ،(القاهرة :1976).

$$
\text { ابن حوقل:ابى القاسم محمد بن على النصيبى"ت:367هج/977م": }
$$


ـكتاب صورة الارض ـالمعروف ايضا ب_كتاب المسالك و الممالك و الفاوز و المهالك ،مطبعة بريل، ط2،(ليدن:1939). ابن خلدون:عبدالرحمن بن محمد "ت:1 • 1 هج/7 • ؛ (م": ـتاريخ ابن خلدون_كتاب العبر وديو ان المبتداء و الخبر فى ايام العرب و العجم و البربر ومن عاصر هم من ذوى السلطات الاكبر،

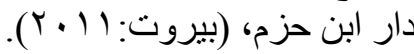
ابن خلكان:ابى العباس شمس الدين احمد بن محمد بن ابى بكر"ت: إب آهج/1282م": ـوفيات الاعبان و انباء ابناء الزمان، دار احياء التراث العربى، ط؟، (بيروت:9 . . ؟). الذهبى:شمس الدين ابى عبداله محمد بن احمد بن عثمان "ت:748هج/1347م": ـناريخ الاسلام ووفيات المشاهير والاعلامهتحقيق:عمر عبد السلام التنمرى،دار الكتاب العربى،(بيروت:1997). ـذيل تاريخ الاسلام ووفيات المشاهير والاعلام،تحقيق:عمر عبدالسلام التدمرى،دار الكتاب العربى،(بيروت:2004).

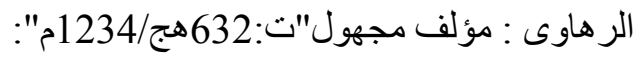

ـتاريخ الرهاوى،ت:الاب ابير ابونا،مطبعة شفيق،(بغداد:1986). الروذراورى :ابو الثجاع محمد بن الحسين "ت:488هج/1095م":

ــذيل كتاب تجارب الامم، تحقيق:م.ف.امدروز، مطبعة شركة التمدن الصناعية ،(القاهرة:1916).

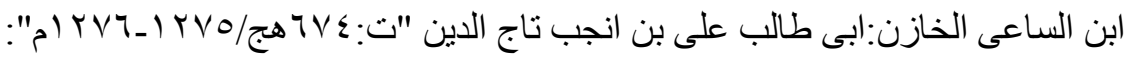
ـالجامع المختصر فى عنوان التو اريخ و عيون السبر، مطبعه السريانيه الكاثوليكية، (بغداد: ـ 9 ( ). السخاوى:شمس الدين ابى الخير محمد بن عبدالرحمن بن محمد"ت:902هج/1496م": ـالذيل التام على دول الاسلام للذهبى ،حققه و علق عليه :اسماعبل مروة،مكتبة دار العربية للنشر والتوزيع ـالكويت ،دار ابن العماد اللنشر و التوزيع،(بيروت:1992). السريانى :مار ميخائيل"ت:596 هج/1199م": ـتاريخ مارميخائيل السريانى ،ت:مار غريغورويوس صليبا شمعون، دار ماردين،(حلب:1996). ابوشامة:شهاب الدين عبد الرحمن بن اسماعيل بن ابر اهيم بن عثمان المقدى الدمشقى الثافعى"ت:665هج/1266م": ـالروضتين فى اخبار الدولتين النورية والصلاحية،منشور ات محمد على بيضون، دار الكتب العلمية ،(بيروت:2002). ابن شداد: بهاء الدين بوسف بن رافع الاسدى"ت:622هج/1234م":

-سيرة صلاح الدين الايوبى "النوادر السلطانية والمحاسن اليوسفية "كتحقيق:محد حسنى مصطفى ، دار القلم العربى ، (حلب:2001).

ابن شداد :عز الدين محمد بن على "ت:684هج/1285م": ـ الاعلاق الخطيرة فى ذكر امر اء الثشام والجزيرة،تحقيق:يحيى عبادة ،وز ارة الثقافة والارشاد القومى ،ديمشق:1978). ابن الثعار الموصلى:كمال الدين ابى المبارك "ت:654هج/1256هم": ـقلائد الجمان فى فر ائد شعر اء هذا الزمان ـالمشهورب_عقود الجمان فى شعراء هذا الزمان، تحقيق:كامل سلمان الجبورى، دار الكتب العلمية، (بيروت:2005). الصفدى :صلاح الدين خليل اييك "ت:764هج/1362م": ـالو افى بالوفيات ،تحقيق:احمد الارناؤط - تركى مصطفى، (بيروت:2000). 


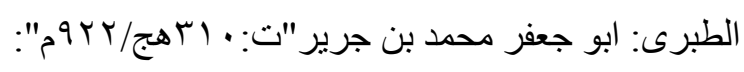

ـتاريخ الرسل و الملوك، تحقيق: محمد ابو الفضل ابر اهيم، ط؛، دار المعارف،( القاهره:9 9 1 ). ابن الطوير:ابو محمد المرتضى عبد السلام بن الحسن القيسر انى "ت:617هج/1220م": -نزهة المقلنين فى اخبار الدولتين ،تحقيق:ايمن فؤاد السيد، المعهد الالمانى للابحاث الثرقية ،ط2،(بيروت:2010). الظاهرى:غرس الدين خليل بن شاهين"ت:872هج/ 1467م": -زبدة كثف الممالك وبيان الطرق و المسالك،مطبعة الجمهورية ،(باريس:1894). ابن العبرى :ابى الفرج جمال الدين"ت:685هج/1286م": ـتاريخ الزمان ،ت:الاب اسحاق ارملة،دار المشرق،(بيروت:2005). عماد الدين الكاتب الاصفهانى :ابو حامد محمد بن محمد"ت:597هج/1200م": ـالفتح القسى فى الفتح القدسى،حقيق:محمد محمود صبح، (د.م.ت). العمرى: شهاب الدين احمد بن فضل الله "ت:749هج/1348م": ـمساللك الابصار فى مماللك الامصار ، السفر الثالث_ممالك الثرق الاسلامى و الترك ومصر و الثشام والحجاز،تحقيق:احمد عبدالقادر الثناذلى،المجمع الثقافى ،(ابوظبى:2003). الغسانى:الملك الاشرف"ت:ب • 1هج/ • . ـ ام": ـ العسجد المسبوك و الجو هر المحكوك فى طبقات الخلفاء و الملوك، تحقيق: شاكر محمود عبدالمنعم، دار التراث الاسلامى للطباعه

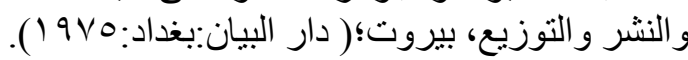
ابن فقيه الهمذانى :ابى عبداله احمد بن محمد بن اسحاق"ت: • 9 هجج/r • 9م":

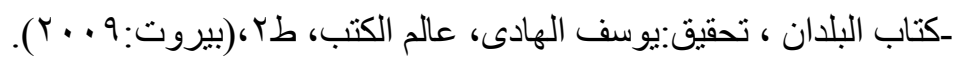
ابو الفيداء:عماد الدين اسماعيل بن محمد بن عمر"ت:732هج/1331م": ـتقويم البلدان، دار الطباعة السلطانية ،(باريس:1840)،ودار الصادر-بيروت. ابن القلانسى: ابو يعلى حمزة "ت:555هج/160م" 1160م": ـذيل تاريخ دمشق، مطبعة الاباء اليسو عيين ،(بيروت:1908). القلقشندى :ابو العباس احمد بن عبداله"ت:820هج/1418م": -صبح الاعشى فى صناعة الانثاء، دار الكتب العلمية،(بيروت:1987). ـمأثر الانافة فى معالم الخلافة،تحقيق:عبد الستار احمد فر اج، عالم الكتب للطباعة والنشر و التوزيع،(بيروت:2006). ابن كثير : ابو الفداء الحافظ الدمشقى "ت:774هج/1372م":

ـالبداية والنهاية، تحقيق:عماد زكى البارودى-خيرى سعيد، المكتبة التوفيقية للطباعة،دار الكتب المصرية،(القاهرة:2008). المجهول:من القرن السابع للميلاد: ـالتاريخ الصغير،ت:الاب بطرس حداد،المركز العلمى العراقى -بغداد دار ومكتبة البصائر للطباعة والنشر والتوزيع و والاعلام،(بيروت:2010). ابن المستوفى :شرف الدين ابى البركات المبارك بن احمد اللخمى الاربلى "ت:637هج/1239م": 
ـتاريخ اربل المسمى نباهة البلد الخامل بمن ورده من الاماتل ،تحقيق:سامى سعيد الصقار ،منشورات وزارة الثقافة الاعلام، دار الرشيد ، (بغداد:1980).

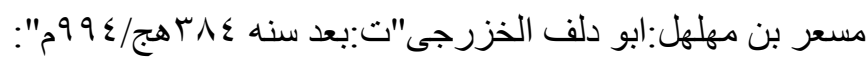
ـالرسالة الثانية، تحقيق:بطرس بولغاكوف و انس خالد، دار النشر للاداب الثرقيه، (موسكو: • 97 ). المسعودى :ابو الحسن على بن الحسين"ت:346هج/957م": -مروج الذهب ومعادن الجوهر ، مطبعة شريعت، (بيروت:1422هجرى). ـالتبيه و الاشر اف،دار ومكتبة الهلال ،(بيروت:1993). مسكويه:ابو على احمد بن محمد"ت:421هج/1030م": ـكتاب تجارب الامم،مطبعة شركة التمدن الصناعية،(القاهرة:1915).

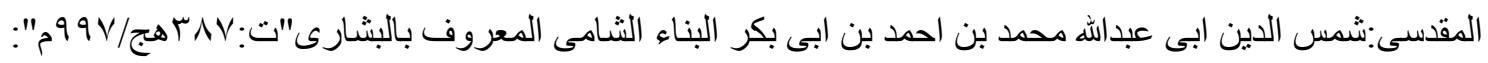
ـكتاب احسن التقاسيم فى معرفه الاقاليم، مطبعه بريل، طب، (ليدن: 7 ـ 9 (). المقريزى:تقى الدين ابى العباس احمد بن على بن عبدالقادر العبيدى"ت:845هج/1441م": ـالسلوك لمعرفة دول الملوك،تحقيق:محمد عبد القادر عطاهنشور ات محمد على بيضون،دار الكتب العلمية ،(بيروت:1997) . ـاتعاظ الحنفاء بأخبار الائمة الفطميين الخلفا،حقيق:محد حلمى محمد احمد،لجنة احياء التراث،مطابع اهرام التجارية،(القاهرة .(1996:

ـكتاب المو اعظو الاعتبار بذكر الخططو الاثار ـالمعروف بـالخطط المقريزية، دار صادر ،(بيروت:د.ت). الهذبانى :الامير عز الدين محمد بن ابى الهيجاء الهذبانى الاربلى"ت:700هج/1300م": -تاريخ ابن ابى الهيجاء الهذبانى ،تحقيق:احمد فريد المزيدى، دار الكتب العلمية ،(بيروت:2004). ابن الوردى :زين الدين عمر بن المظفر "ت:749هج/1348م": ـتاريخ ابن الوردى -تتمة المختصر فى اخبار البشر،دار الكتب العلمية ،(بيروت:1996). اليافعى:عبدالله بن اسعد بن على بن سليمان "ت:768هج/1363م": ـمر اة الجنان و عبرة اليقظان فى معرفة مايعتبر من حوادث الزمان،دار الكتب العلمية، (بيروت:1997).

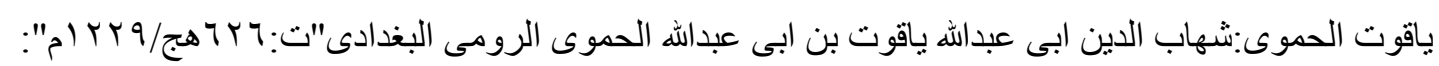

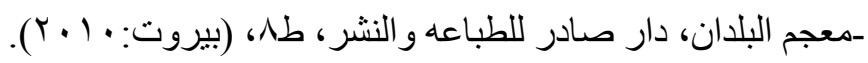
-بدزانمانى كودى:-

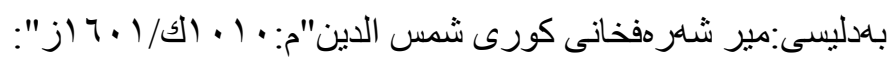

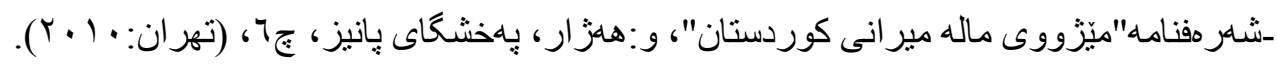

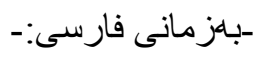

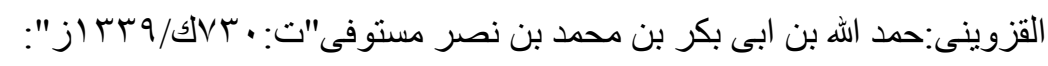

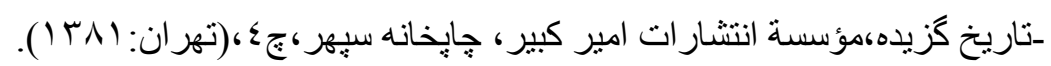




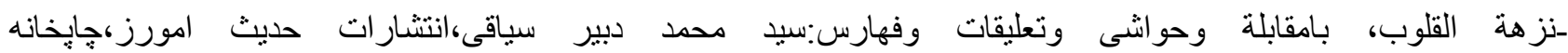

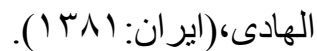

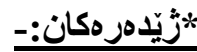

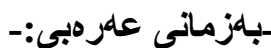

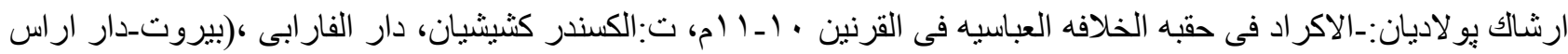

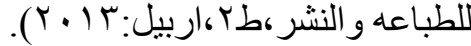

تريفه احمد عثمان البرزنجى:_اسهامات علماء الاكراد فى بناءالحضاره الاسلاميه" خلال قرنين السابع و الثامن الهجريين-علوم

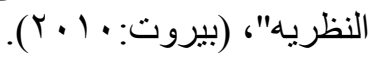

حكيم عبدالرحمن زبير البابيرى:-مدينة خةلات"دراسة فى تاريخها السياسى والحضارى 493-641هج/1100-1243م"،دار سبيريز ،(دهوك:2005).

رشيد الجميلى :-دولة الاتابكة فى الموصل بعد عماد الدين زنكى"641-63هج"، دار النهضة العربية للطباعة و النشر،(بيروت:1970).

زرار صديق :-كردستان فى الثامن الهجرى"در اسه فى تاريخها السياسى و الاقتصادى"،(اربيل: ( . ب؟). السيد محسن الامين:-خطط جبل عامل ،الدار العلمية للطباعة و النشرو التوزيع،(د.م:1983).

$$
\text { عبدالرحمن قاسملو: كردستان والاكر اد،(بيروت:د.ت). }
$$

عمادالدين خليل: الامارات الارتقية فى الجزيرة والثام"465-812هج/1072-1409" على المقاومة الاسلامية للصليبيين و التتر،مؤسسة الرسالة، (بيروت:1980).

$$
\text { كى لسترنج: -بلدان الخلافة الشرقية،تات: بشير فرنسيس- كوركيس عو اد،(بيروت:1985). }
$$

محسن محمد حسين : ـقلائد الجمان "مصدر الدراسة جو انب من تاريخ اربيل والكرد ، من منشور ات الاكاديمية الكردية،مطبعة حاجى هاشم ،(اربيل:2012).

محمد امين زكى بك: -خلاصده تاريخ الكرد وكردستان"تاريخ الدول و الامار ات الكرديه في العهة الاسلامى"،ت:محمد على عونى،

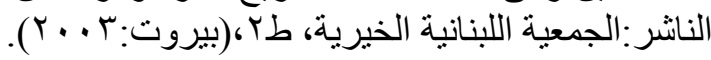
موسى مصطفى الهسنيانى : -سنجار دراسة فى تاريخها السياسى والحضارى من521-600هج/1127-1261م ،دار

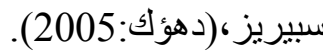
نافع توفيق العبود:-الدولة الخوارزمية "نثاءتها وعلاقتها مع الدولة الاسلامية نظمها العسكرية والادارية 490-628هج/10971231م"، مطبعة جامعة بغداد ،(بغداد:1978). -بلةزمانى كودى:-

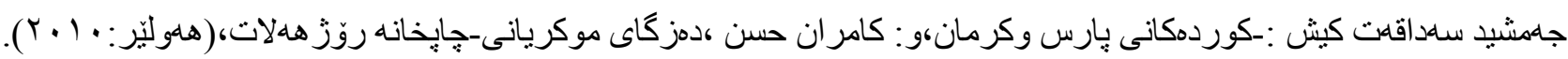

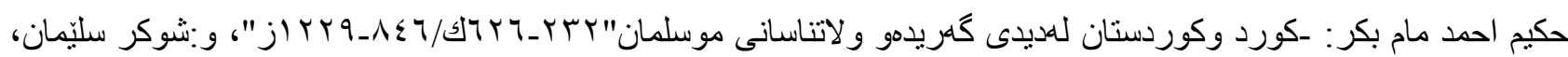

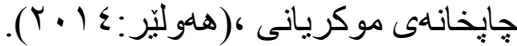

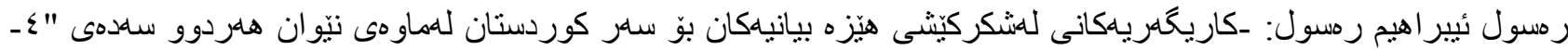

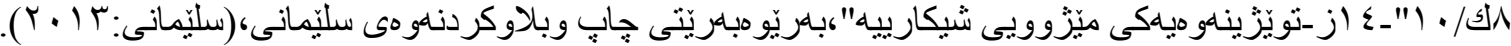

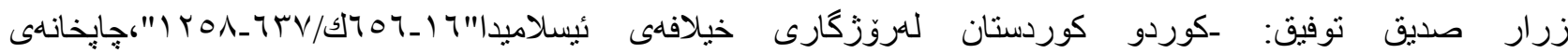

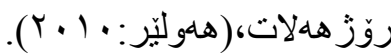




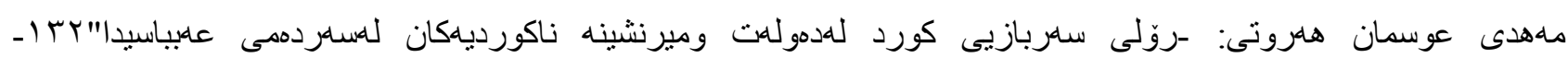

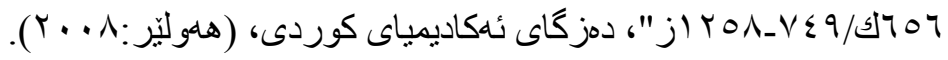

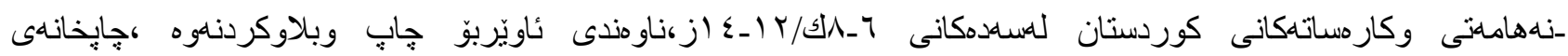

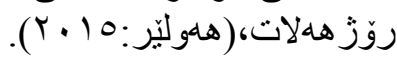

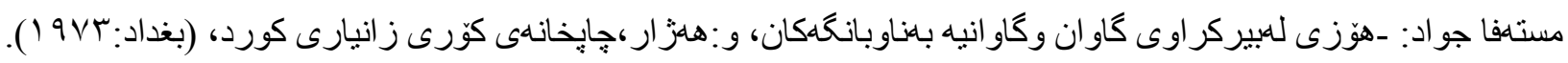

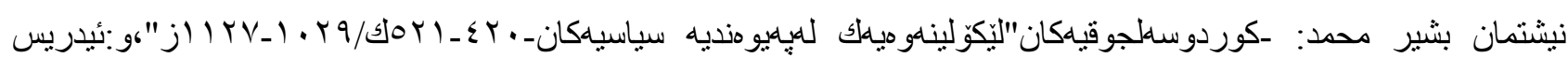

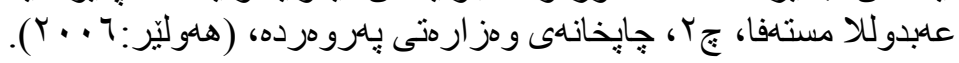

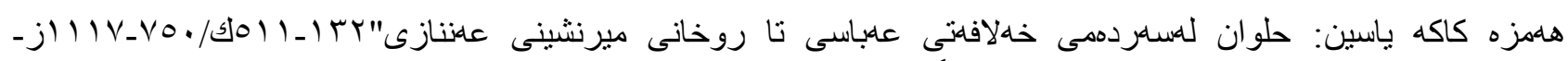

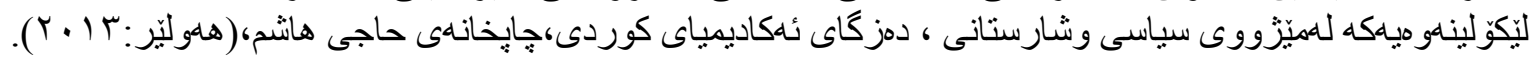
-بذزمانى فارسنى:-

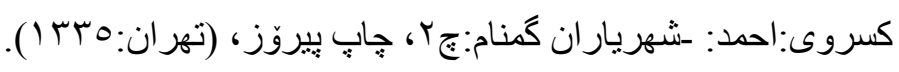
-باهزمانى ئينغليزى:-

Friedrich Justus,Carl: -The black death in the fourteenth century,p.45-77.

*نامهفى زانكوّيحي:

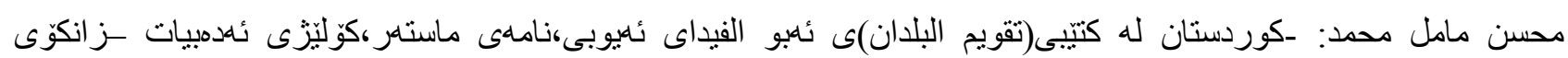

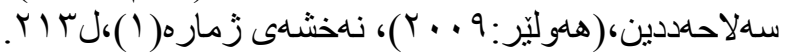

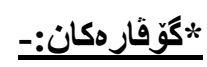
-بهزمانى كوردى:-

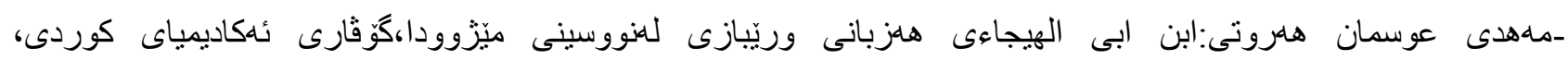

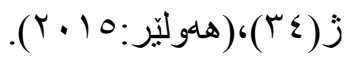
-بالةمانى عهرهبى:-زرار صديق نوفيق:النفوذ الفاطمى فى بلاد الكرد"دراسة فى العلاقات الفاطمية ـالكردية"،كوّارا زانكوّيا دهوّك، هزمارا

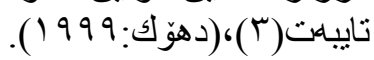
مجهول:لبنان مباحث علمية واجتماعية ،مج1،منشور ات لحد خاطر، ط3،(بيروت: 1993). -بهزمانى فارسى:-يعقوب ازند:مرك سيا در تاريخ ميانه اير ان، فصلنامه مطالعات تاريخى، شماره دوم- سال اول،(مشهد:^؟ب ا ). 


\section{ياشكوّى زُماره( (1)-نهخشهى هلريْم وناوجه كوردنشينهكان}

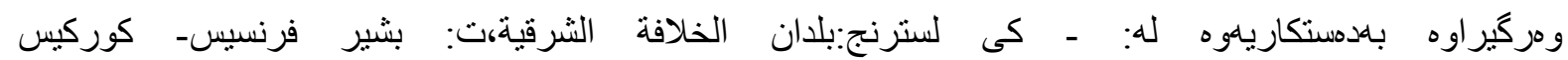

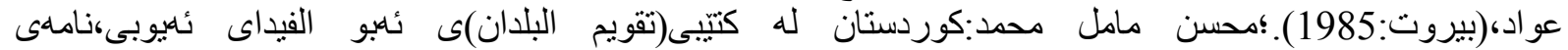

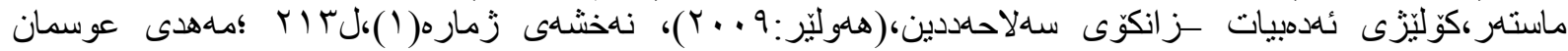

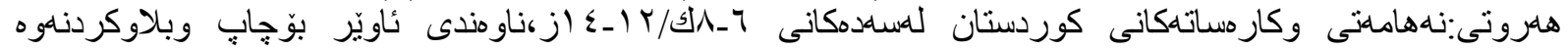

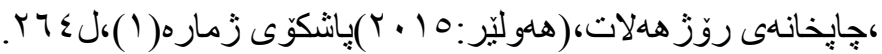

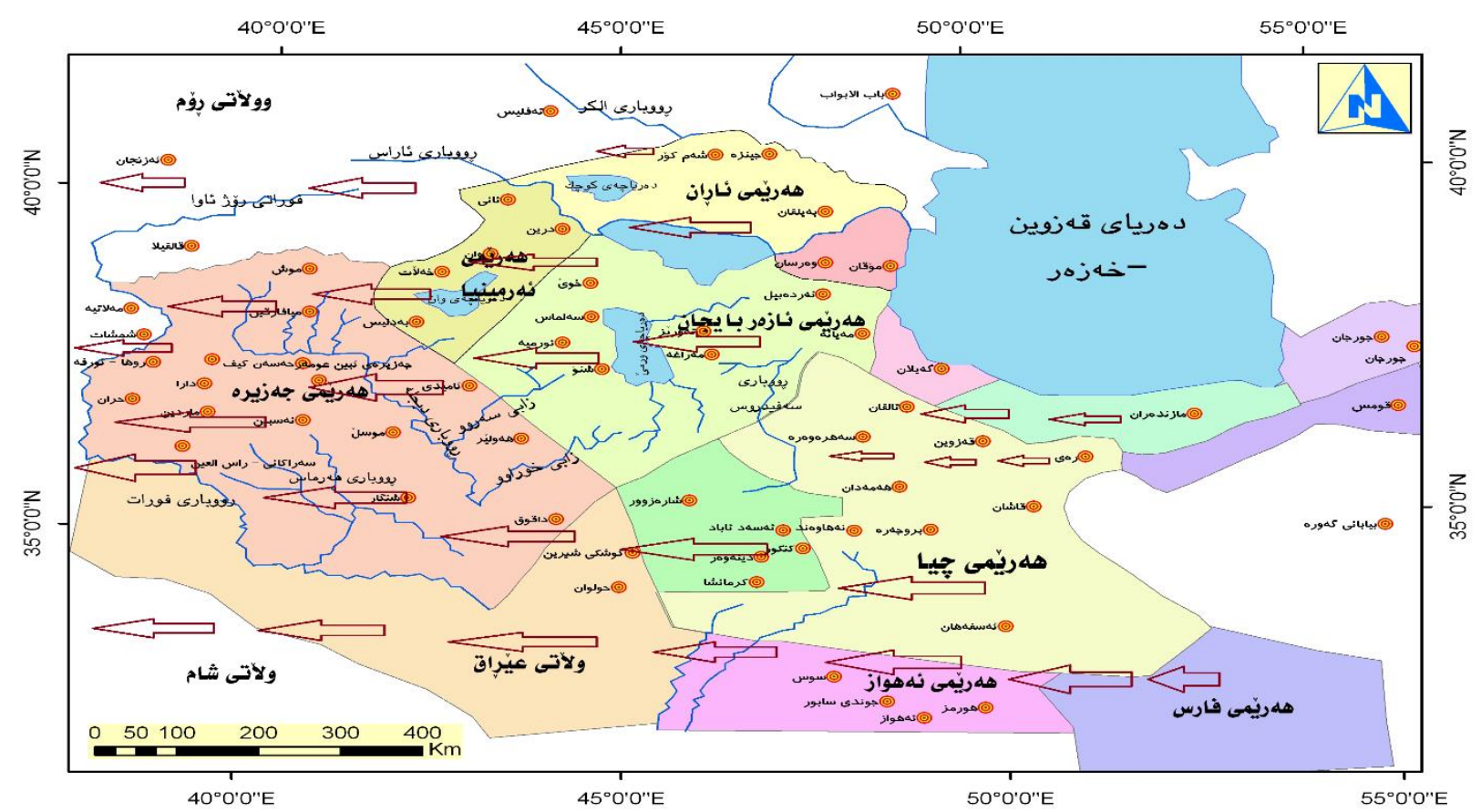

